\title{
The microstratigraphic record of human activities and formation processes at the Mesolithic shell midden of Poças de São Bento (Sado Valley, Portugal)
}

\author{
Carlos Duarte $^{1}$ (D) $\cdot$ Eneko Iriarte $^{2} \cdot$ Mariana Diniz $^{3} \cdot$ Pablo Arias ${ }^{1}$
}

Received: 13 February 2017 / Accepted: 31 May 2017

(C) Springer-Verlag Berlin Heidelberg 2017

\begin{abstract}
Shell midden formation is largely controlled by anthropogenic processes, resulting from human exploitation of aquatic resources. This makes shell middens archives of both human behaviour and palaeoenvironmental records. However, their often complex stratigraphy hampers the isolation of individual anthropogenic events. In the central/ southern coast of Portugal, extensive inland estuaries were preferential settings for Mesolithic groups from c. $6200 \mathrm{cal}$ BC. Here, we present a microstratigraphic approach to the shell midden of Poças de São Bento, one of the largest and best-known sites in the Sado Valley. The microfacies approach was based on sedimentary components, their abundance and arrangement, and post-depositional processes. Anthropogenic processes identified as tossing events and anthropogenically reworked deposits allowed inferences on spatial organisation, preferential refuse areas, occupational surfaces, and temporality of the occupations. The presence of calcareous pebbles in the anthropogenic, shell-rich sediments, together with foraminifera, presumably from the estuarine marshes, is compared with the regional geology, providing a hypothetical location of
\end{abstract}

Electronic supplementary material The online version of this article (doi:10.1007/s12520-017-0519-0) contains supplementary material, which is available to authorized users.

Carlos Duarte

cduarte.as@gmail.com

1 Instituto Internacional de Investigaciones Prehistóricas de Cantabria, Universidad de Cantabria, Av. de los Castros 52, 39005 Santander, Cantabria, Spain

2 Laboratorio de Evolución Humana, Dpto. Historia, Geografía y Comunicación, Universidad de Burgos, Plaza de Misael Bañuelos s/n, Edificio I+D+i, 09001 Burgos, Spain

3 Centro de Arqueologia UNIARQ, Faculdade de Letras, Universidade de Lisboa, 1600-214 Lisbon, Portugal the shellfish gathering. The microstratigraphy described reveals a full internal dynamic in the formation of the apparently homogeneous shell midden layer. The human activities inferred at Poças de São Bento have many similarities with those reported for Cabeço da Amoreira in the nearby Tagus palaeoestuary. This evidence points to the need for further micromorphological approaches in similar deposits. The study of shell midden formation processes, through integrative microcontextual approaches, plays a major role in understanding Mesolithic societies in the large early Holocene estuary environments of Atlantic Iberia.

Keywords Mesolithic $\cdot$ Shell middens $\cdot$ Sado Valley Micromorphology $\cdot$ Human activities $\cdot$ Formation processes

\section{Introduction}

Shell middens are particularly interesting archaeological deposits because of their largely anthropogenic nature, directly resulting from human activities, which makes them sedimentary deposits that can be considered artefacts in themselves. The study of such contexts, however, faces several difficulties in the reconstruction of the human-driven formation processes. Shell-rich deposits might present macroscopically an apparent sedimentary homogeneity that in the field hampers the isolation of the individual events involved in the accretion of these types of deposits (Stein 1992; Gutiérrez-Zugasti et al. 2011). J. Roche (1966) noted in the Muge shell middens in Portugal that individualised occupations relatively independent from each other might generate continuous stratigraphic sequences, together with the artefacts embedded in those sediments. This has serious implications in archaeological interpretation due to unnoticed mixing of 
materials from different events. Such an intricate stratigraphic record also makes shell midden deposits archives of detailed information about both human behaviour and the palaeo-ecological conditions they exploited. Seasonality patterns are one of the aspects of human behaviour that have recently been extracted from shell mound deposits (see e.g. Surge et al. 2013; Colonese et al. 2009, 2012), as they enable season of shellfish gathering to be determined through oxygen isotopic analysis of shell growth lines. At the regional scale, shell middens have also been explored as palaeoenvironmental proxies. Their location has been used for mapping changes in Holocene costal environments (Villagran and Giannini 2014) and isotope and elemental analysis of shell growth lines have also been used for palaeoclimate reconstructions, namely sea surface temperature variations (Gutiérrez-Zugasti et al. 2015). Both aspects of shell middens potential for archaeological interpretations (human behaviour and palaeoenvironment) are enhanced by the fact that this type of deposit is known in coastal areas worldwide in different chronologies (Álvarez et al. 2011; Balbo et al. 2011).

In southwestern Iberia, in particular, intensive shellfish exploitation during the Mesolithic led to the accumulation of shell middens, generally associated with adaptations to the changing environment in the early Holocene (GutiérrezZugasti et al. 2011). Sea level rise caused the formation of extensive inland estuaries (Dias et al. 2000), such as those of the Tagus and Sado Rivers, that were preferential settings for the Mesolithic groups from the late seventh millennium cal BC (Bicho et al. 2010; Diniz and Arias 2012; Peyroteo Stjerna 2016).

Here, we present a microstratigraphic approach based on micromorphological analysis of the shell midden of Poças de São Bento, one of the largest of the 12 Mesolithic shell midden sites in the Sado Valley. The shell midden layer is not continuous, however, which has been interpreted as the result of mainly lateral accretion of shell-rich deposits (rather than superposition) by semisedentary occupations, resulting in a laterally discontinuous shell midden layer (Diniz and Arias 2012; Arnaud 2000; Larsson 1996). Through micromorphological analysis, we aimed to recognise single events of human activities involved in shell midden formation. Our approach also sought to make a spatial correlation between different sampled areas of the site, in order to identify any sedimentological differences between spatially disconnected shell midden accumulations, eventually associated with different function. Furthermore, we wished to clarify if there are any gaps in sedimentation related to absence of occupation. It was also our concern to address the diagenetic processes that the shell midden underwent, in order to provide an integrative assessment, at high resolution, of preservation conditions of the human-derived deposits and the artefacts in them.

\section{Poças de São Bento in its geological and archaeological context}

Poças de São Bento is an open-air site on a gentle slope, limited to the SE by a brook belonging to a small subsidiary basin of the Sado River (Fig. 1). Nowadays, the site is $3 \mathrm{~km}$ south of Sado, on a Cenozoic platform, at an altitude of c. $80 \mathrm{~m}$ above present mean sea level. The Sado Basin is incised into this platform exposing successive layers of Miocene conglomerates and sandstones in quite steep slopes. The platform is covered by a Pleistocene/Holocene aeolian sand cover, on which the shell midden rests. The location of Poças de São Bento is substantially further inland, when compared to the other sites, which tend to follow a somewhat consistent location pattern close to the erosion edge of the platform, usually with good overview of the Sado alluvial plain. Several shell midden sites are currently known in both margins of the Sado, Arapouco being the furthest downstream (Fig. 1). Poças de São Bento is one of the two largest sites, with an area of c. $3500 \mathrm{~m}^{2}$, only exceeded by Cabeço do Pez, the furthest upstream shell midden known, with an area of $\sim 4000 \mathrm{~m}^{2}$. The alluvial plain is characterised, today, by extensive rice fields, and the Vale dos Açudes stream is controlled by a system of dams and largely modified by recent agricultural activities that make it extremely difficult to visualise the natural course of the hydrographic basin.

The existence of estuarine marshland environments upstream of Arapouco during the Mesolithic is an open question and currently the object of on-going investigations. Preliminary data based on sediment cores from the Sado valley infill suggest that there was marine influence near Arapouco (located $\sim 20 \mathrm{~km}$ from the present-day estuary), between c. 1650 and $1400 \mathrm{cal}$ BC, when mean sea level was similar to the present (Costa et al. 2015, 2017). However, there is not yet sufficient data to characterise the environment in the shell middens area at $6000 \mathrm{cal} \mathrm{BC}$, when, according to sea level curves proposed for the Portuguese coast, mean sea level was c. $10 \mathrm{~m}$ below the present level (Dias 2000).

The discovery of this cluster of shell middens with necropolises in the 1930s motivated extensive excavation programmes during the 1950s and 1960s by M. Heleno. A later project directed by J. Arnaud and L. Larsson, in the 1980s, carried out systematic excavations, sampling and study of artefactual collections (Arnaud 1989, 2000; Larsson 1996, 2010). Since 2010, a collaborative project between the University of Cantabria (Santander, Spain) and the University of Lisbon (Portugal) has resumed the excavations at Poças de São Bento, as well as in other sites in the Sado Valley (Arias et al. 2015; Diniz and Arias 2012). 


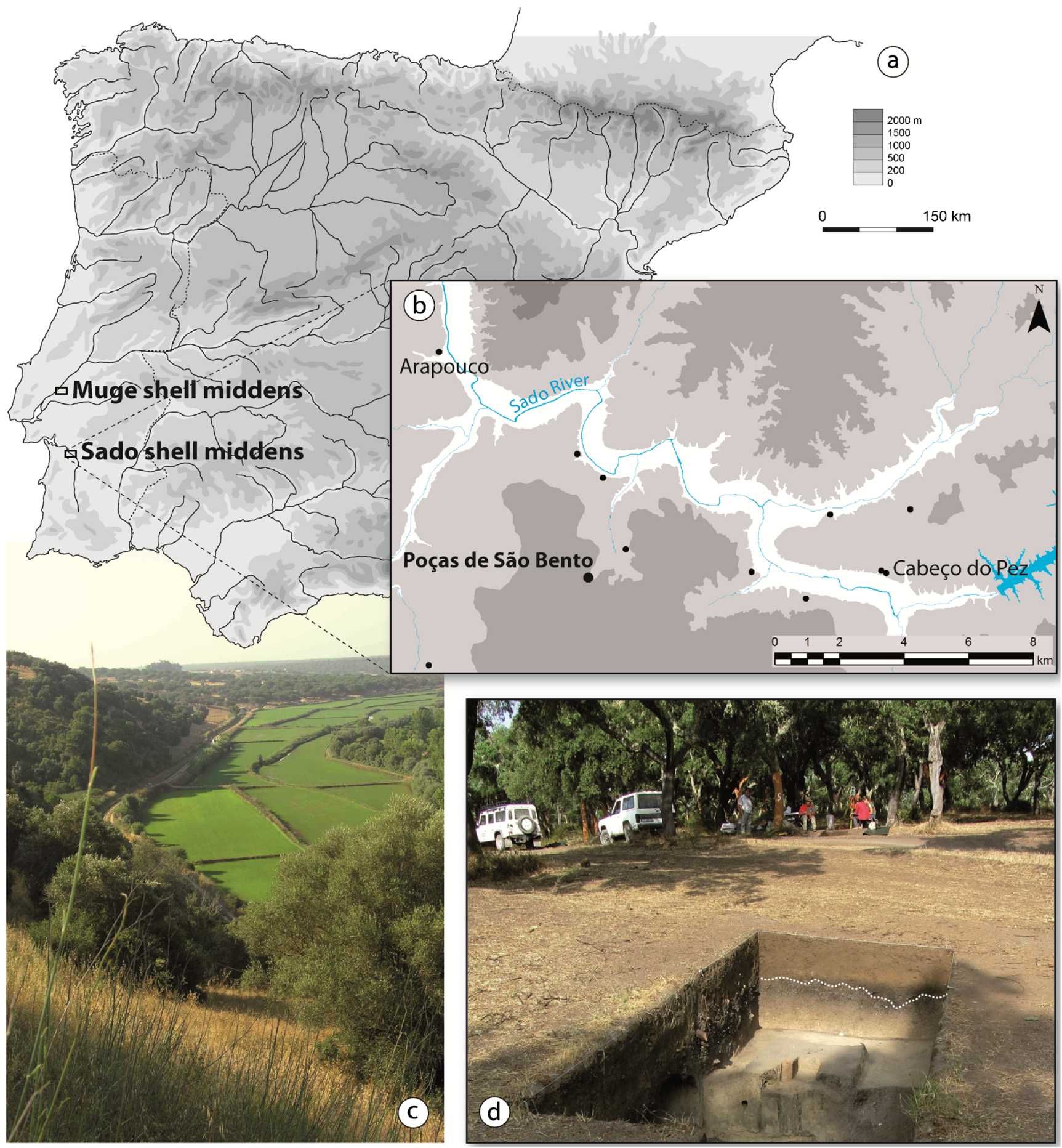

Fig. 1 Location and surroundings of Poças de São Bento. a Geographical location of the Sado and Muge shell middens in the Iberian Peninsula. b Close-up of the Sado Valley with location of Poças de São Bento, the sites mentioned in the text of Arapouco and Cabeço do Pez, and the other known shell midden sites (black dots); note that Poças de São Bento is a considerable distance from the Sado in comparison with

the other sites. $\mathbf{c}$ View of the Sado alluvial plain, now extensive rice fields, from a typical location of most shell middens, close to the edge of the erosion platform; note the steepness of the slopes. $\mathbf{d}$ General view of the site of Poças de São Bento, with Area 9 in the foreground, from the NE (see Fig. 2), during the 2015 excavation; the surface of the shell midden layer here is indicated by the dashed line in the front section

Previous publications on Poças de São Bento have focused mainly on its artefactual assemblages, namely lithic technology (Araújo 1995-1997; Araújo et al. 2015), raw material provenance (Pimentel et al. 2015), funerary practices

(Stjerna 2015), human dietary reconstructions (Umbelino et al. 2007; Fontanals-Coll et al. 2014; Peyroteo Stjerna 2016) and macrobotanical, non-woody remains (LópezDóriga et al. 2016). 


\section{Stratigraphic and chronological framework}

At Poças de São Bento shell midden, the stratigraphy is quite uniform in all excavated areas and test pits carried out by the current archaeological project, with some variations, mainly concerning the thickness and density of shells in the deposits. Arias et al. (2015) classified the overall site stratigraphy in phases, combining the previous and new radiometric dates with macroscopic observations in the field, as summarised in Table 1.

The shell midden deposits rest on a cover of Pleistocene/ Holocene aeolian sand. These sands are fairly homogeneous clast-supported and weakly compacted, except for the occurrence of post-depositional calcareous concretions related to root activity (Fig. 2c). An OSL age for Phase A sediments, in Area 9, associates the stabilisation and burial of these basal sands slightly prior to the beginning of the Holocene (Table 1).

The set of ${ }^{14} \mathrm{C}$ dates (Table 1) suggest that the earliest occupation at Poças de São Bento is that of Phase B, which corresponds to the shell midden layers, dated to between the late seventh millennium cal $\mathrm{BC}$, and the sixth millennium cal BC. Broadly speaking, the shell midden deposits exhibit a greyish colour and a maximum thickness of around $80 \mathrm{~cm}$ and are sedimentologically quite homogeneous, loose sands with highly fragmented shells. These sediments enclose loosely packed centimetric pebbles of allochthonous origin - some of them used as lithic raw material (see Table 2) - as well as lithics and bones, usually poorly preserved due to weathering and bioturbation. Spatially, however, each of the archaeological accumulations is quite sparse, with common lateral discontinuities, which result in patchy accumulations with gradual contacts with the under and overlying sediments; they are difficult to individualise topographically. Some sedimentological stratification within the shell midden layer is visible only in deposits in Areas 9 and 11 (Fig. 2). Here, the archaeological deposits present some internal stratification, with centimetre-thick lenses with sharp contacts, predominantly formed by quite complete shell valves.

In terms of habitat features, hearths and putative postholes have been reported at the site (Arnaud 1989, 2000; Larsson 1996). Some negative structures, or pits, were identified dug into the Pleistocene/Holocene basal sands, usually under a layer of shell-rich Phase B sediments; the infilling seems to be sedimentologically equivalent to the same Phase B sediments (Fig. 2c). In Area 1, these sediments included a dog burial (Arias et al. 2015). The human burials so far identified at Poças de São Bento were found in the basal sands below the lower contacts of the shell midden layer. They are concentrated in an area of the site's estimated perimeter extensively excavated in former projects (Fig. 2).
Overlying the shell midden layers are the greasy, dark sediments of Phase C, which post-date the Mesolithic, a pedological horizon affecting the upper part of shell-rich sediments (Fig. 2). The stratigraphic units corresponding to Phase $\mathrm{C}$ exhibit intense post-depositional bioturbation and admixture of pedogenic and anthropogenic materials. The radiocarbon result from Phase $\mathrm{C}$ sediments in Area 6, from a sample of total organic matter of sediment, revealed an early fifth millennium cal BC chronology, coherent with the scarce Neolithic pottery sherds dispersed in this layer (Arias et al. 2015). Finally, the uppermost sediments, Phase D, have a sharp lower contact with Phase $\mathrm{C}$ sediments and correspond to the present-day soil surface.

\section{Materials and methods}

In geoarchaeology, micromorphology refers to the microscopic study of undisturbed and oriented blocks of artificially consolidated "soils, sediments, and archaeological features and materials in thin section" (Goldberg and Aldeias 2016). This technique allows the observation of the cultural remains in their surrounding sedimentary matrix, preserving the contextual arrangement of the deposits (Courty et al. 1989; Goldberg and Berna 2010). In archaeological contexts, micromorphology has proven to be especially useful for several relevant aspects of the archaeological record interpretation, such as the distinction between anthropogenic and natural processes (Aldeias et al. 2014; Mallol et al. 2010; Goldberg et al. 2003; Karkanas 2002), including the nature and significance of stratigraphic contacts and discontinuities (Mallol and Mentzer 2015). It has been particularly successful in the identification and assessment of the degree of preservation of anthropogenic features, such as combustion features (Mentzer 2014; Aldeias et al. 2012) and occupational surfaces - including Mesolithic ones (Zerboni 2011) - and the recognition of human activities such as bedding, trampling (Goldberg et al. 2009; Miller et al. 2013) or intentional reworking of debris (Shillito et al. 2011; Sherwood and Kidder 2011). These types of activities are very often only discernible at this microscopic scale.

The concept of microfacies has been used to synthesise deposits that share a set of specific microscopic attributes in thin section (Courty 2001; Flügel 2004). The subsequent interpretation of those attributes, a combination of sedimentary components, their spatial organisation and geometry, or other parameters, when consistently isolated from adjacent deposits, is interpreted as the result of a certain process, natural or anthropogenic. In archaeological sediments, different microfacies types might be recurrently in close association (e.g. Goldberg et al. 2009). 


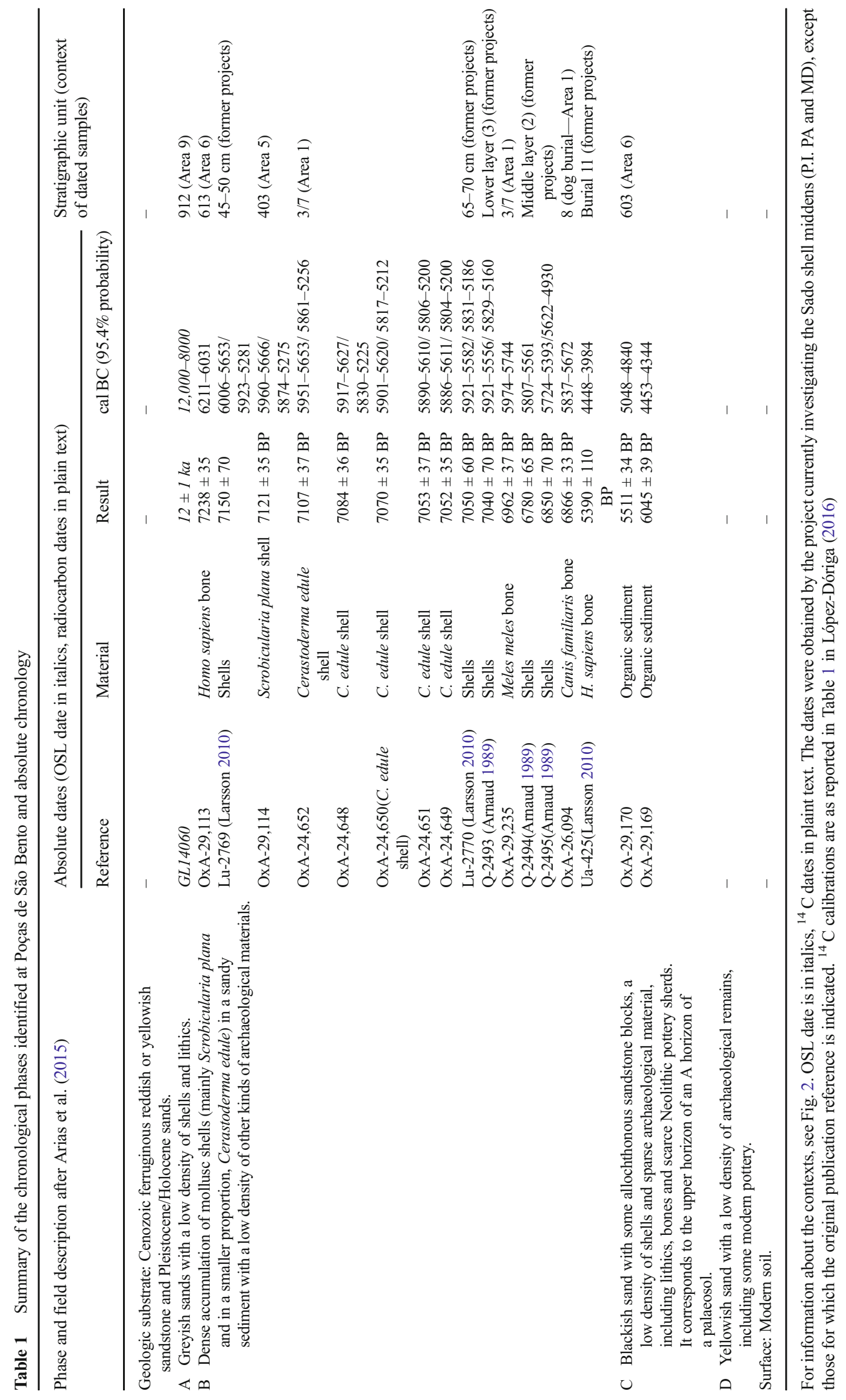




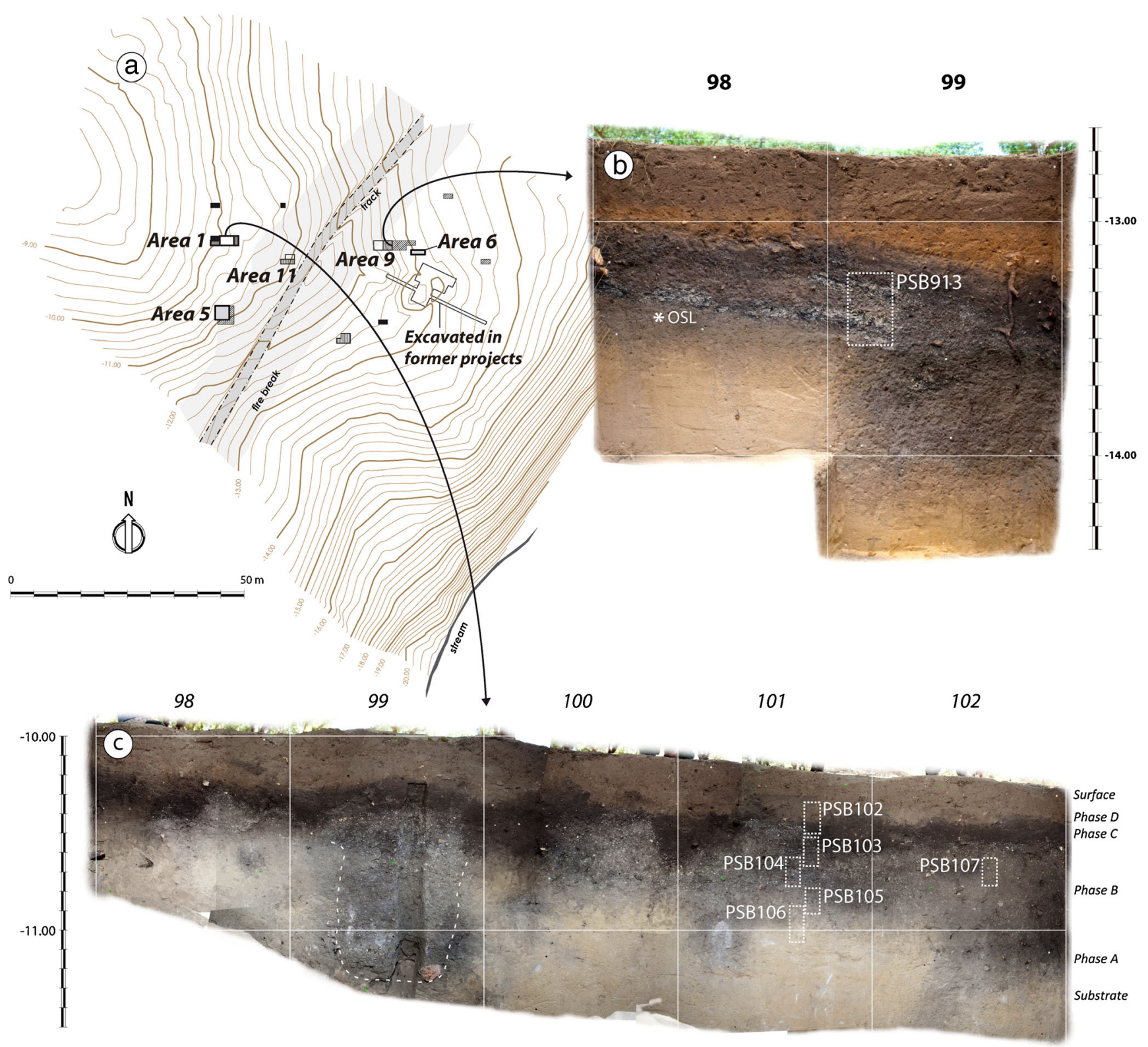

Fig. 2 The site of Poças de São Bento. a General site topography with indication of Areas mentioned on the text, 1, 5, 6, and 9, and other excavated areas. b Sampled profile in Area 9, with indication of the micromorphological block sample PSB913; note the oblique orientation, superposition and irregular upper contacts of the shell

This approach helps to describe anthropogenic-derived millimetre-thick strata, which can be difficult to isolate in the field, and scale up their relation with the broader archaeological context. The microfacies approach can, therefore, contribute significantly to the reconstruction of formation process and human activities at a given site.

A microfacies approach has been successfully applied in shell mounds on the southern coast of Brazil (Villagran 2014b, Villagran et al. 2009) and in the ethnoarchaeological work at historical shell middens in Tierra del Fuego (Villagran et al. 2011; Balbo et al. 2010). Recently, this midden layers. The OSL sampling location is also marked (OSL). c Sampled profile in Area 1 with chronological phases after Arias et al. (2015), with indication of the micromorphological block samples PSB102 to PSB107; note the homogeneity of the shell midden layer (Phase B) and the pit feature in square 99 (dashed line)

approach allowed for the recognition of different types of deposits in primary and secondary positions, due to both natural and anthropogenic processes, as well as occupational surfaces, within the Cabeço da Amoreira shellmound (Aldeias and Bicho 2016), a site which is in the regional vicinity and roughly contemporaneous to the deposits of Poças de São Bento studied here.

The micromorphological samples presented here were collected in Areas 1, 5 and 9 (Fig. 2a), attending to specific stratigraphic features, highlighted below (see also Fig. 2b, c). The sampling consisted of carving out the 
Table 2 Description and genetic interpretation of the main components observed in Poças de São Bento thin sections

\begin{tabular}{llll}
\hline Component & Description & Genetic interpretation & Thin \\
\hline Silt and sand mineral grains & $\begin{array}{c}\text { Sand and silt sized mineral grains are the } \\
\text { dominant component in all thin sections. } \\
\text { Their composition consists of 80\% }\end{array}$ & $\begin{array}{c}\text { The lithologies and general roundness of } \\
\text { the grains reflect the }\end{array}$ \\
& $\begin{array}{l}\text { Pleistocene/Holocene sand cover on } \\
\text { quartz, 15\% feldspar (microcline and }\end{array}$ & $\begin{array}{l}\text { which the shell midden rests, } \\
\text { continuously reworked by human and } \\
\text { and 5\% opaque minerals. Shapes vary } \\
\text { from sub-angular to well-rounded. Very }\end{array}$ & $\begin{array}{l}\text { natural processes and incorporated into } \\
\text { the archaeological sediments. }\end{array}$
\end{tabular}

Pebbles

Mollusc shells

Wood charcoal

Clay

Char
Shell fragments of peppery furrow (Scrobicularia plana) are dominant in all shell-rich sediments at Poças de São Bento. Cockle (Cerastoderma edule) shells are less frequent and less fragmented. Depending on the context, the degree of calcium depletion, fragmentation, orientation and organisation patterns are variable.

Fishbones and mammal bones Mammal bones fragments are extremely rare although existent in all thins sections and only in two instances exceed sand size. Fishbones, including vertebra are present in all thin sections of shell-rich sediments. Bones exhibit some physical weathering, occasional calcium carbonate mineralisation and rarer signs of burning (reddish colour).

Well-preserved fragments from fine sand size up to $1 \mathrm{~cm}$ are abundant, particularly in shell-rich sediments.

Very little clay was observed in the thin sections. In shell midden layers, it occurs mostly as small amounts of clay attached to shells or coarser sand grains, sometimes forming connecting bridges between those (chitonic/gefuric c/f related distributions). Also, very few, isolated aggregates were identified. Two different main compositions were distinguished in the shell midden layers:

1. Reddish brown, stipple speckled b-fabric, with organic matter inclusions.

2. Orange/yellow, crystallitic b-fabric, with silty mineral inclusions.

Both types of clay aggregates occur in $\mathrm{mF}$ type 5a (interconnected shells) deposits (see below).

Char aggregates are present in shell-rich sediments, some exceeding sand size, with thei characteristic amorphous shape
Thin sections

103.2, 104.1, 104.2, 105.1, $105.2 ; 107,108,913.1$

Pleistoces, which are absent in the Pleistocene/Holocene sand cover substrate, and their association with shell-midden sediments indicate transport to the site by humans (from elsewhere in the valley, where such materials outcrop), possibly as a by-product of shellfish gathering and other sediment-bearing activities. An intentional transport for knapping and structuration of combustion and other features is also a possibility.

Anthropogenic input resulting from shellfish resources exploitation.

All, except 102

Animal/fish processing and consumption by humans at the site.

103.1, 103.2, 104.1, 104.2, 105.1, 105.2, 107, 108, 913.1, 913.2, 913.3, 913.4

Anthropogenic combustion activities.

All, except 106.1 and 106.2

Origin uncertain, probably result of shell 913.1, 913.2, 913.3, 913.4 gathering in estuarine marshes, redeposited by post-depositional water percolation.

Probably from charred plant-derived secretions (e.g. resin) the result of combustion activities, giving the
$104.2,105.1,107,913.1$ 
Table 2 (continued)

\begin{tabular}{|c|c|c|c|}
\hline Component & Description & Genetic interpretation & Thin sections \\
\hline & $\begin{array}{l}\text { with vesicles resulting from trapped air } \\
\text { bubbles and dehydration cracks. In some } \\
\text { cases, the charred mass is optically } \\
\text { contiguous to wood charcoal. }\end{array}$ & $\begin{array}{l}\text { common association with wood } \\
\text { charcoal. The macrobotanical } \\
\text { assemblage evidences a significant } \\
\text { exploitation of pine (Lopéz-Doriga } \\
\text { 2016). }\end{array}$ & \\
\hline Foraminifera & $\begin{array}{l}\text { Few and poorly preserved isolated } \\
\text { foraminifera were observed in shell-rich } \\
\text { sediments. }\end{array}$ & $\begin{array}{l}\text { Anthropogenic, non-intentional input } \\
\text { associated with shellfish gathering in } \\
\text { the estuarine marshes. }\end{array}$ & $104.1,913.2$ \\
\hline Calcified filaments & $\begin{array}{l}\text { Very common in shell-rich and especially in } \\
\text { cemented sediments, filaments ( } 100 \mu \mathrm{m} \\
\text { or more in length and } 5-10 \mu \mathrm{m} \text { wide) } \\
\text { sometimes branching, reproducing the } \\
\text { mycelial growth of fungal hyphae with } \\
\text { (taphonomic) micritic nature and a } \\
\text { characteristic inner hollow left after the } \\
\text { fungi decomposition. }\end{array}$ & $\begin{array}{l}\text { Charred and calcified fungi } \\
\text { (Cenococcum geophilum) sclerotia } \\
\text { have been identified in the } \\
\text { macrobotanical assemblage and } \\
\text { associated to ancient or dead wood } \\
\text { exploitation (López-Dóriga 2016). } \\
\text { These fungi also develop hyphae like } \\
\text { those seen in thin section, too small to } \\
\text { be recovered in flotation, but that can } \\
\text { be related to the sclerotia species } \\
\text { identified in the archaeobotanical } \\
\text { study, also calcified. This correlates } \\
\text { well with elements in the } \\
\text { macrobotanical analysis. }\end{array}$ & All \\
\hline Insect faecal pellets & $\begin{array}{l}\text { Very frequent, both humified and calcified, } \\
\text { oblong to spherical granules are } \\
\text { ubiquitous. }\end{array}$ & $\begin{array}{l}\text { Charred and calcified termite excrements } \\
\text { have been identified in the } \\
\text { macrobotanical assemblage at Poças } \\
\text { de Sao Bento and associated with } \\
\text { ancient wood exploitation } \\
\text { (López-Dóriga 2016). Humic pellets } \\
\text { (not charred or calcified), from other } \\
\text { insects also occur, associated with } \\
\text { recent bioturbation. }\end{array}$ & All \\
\hline Phytoliths & $\begin{array}{l}\text { Rare, elongated phytoliths were observed } \\
\text { associated with the highly organic } \\
\text { anthropogenic sediments, with possible } \\
\text { signs of alteration. }\end{array}$ & $\begin{array}{l}\text { Given their occurrence in highly organic } \\
\text { anthropogenic sediments, they are } \\
\text { possibly related to plant processing at } \\
\text { the site by humans. }\end{array}$ & PSB108 \\
\hline Fresh plant material & $\begin{array}{l}\text { Roots, plant tissue and plant cells are } \\
\text { ubiquitous elements, often in close } \\
\text { association with humic faecal pellets. }\end{array}$ & Recent bioturbation. & All \\
\hline
\end{tabular}

blocks from the profiles and using pre-plastered bandages to pack the exposed surface of the blocks and ensure their undisturbed extraction. After they were wrapped in plastic, the orientation was marked on each block.

The deposits in Area 1 are well representative of the overall site chronostratigraphic scheme explained above. Therefore, a vertical sampling strategy was undertaken (Courty and Fedoroff 2002) covering the full sequence in the North profile (samples PSB102 to PSB106) (Fig. 2c). The shell midden here consists of one homogeneous layer $\sim 35 \mathrm{~cm}$ thick (stratigraphic unit 3/7). Additionally, two lateral samples were taken: PSB107 was collected in the contact between stratigraphic units $3 / 7$ and 12 (Fig. 2c), distinguished in the field by the relative lower abundance of shells in unit 12; PSB108 was collected in the East profile in order to cover a zone of discontinuous calcareous concretions, which characterise the base of unit 12 .
From Area 5, one thin section (PSB510) was analysed, from a heavily and homogeneously concreted area at the base of the shell midden layer, which here is quite thick $(50-60 \mathrm{~cm})$. As mentioned above, Area 9 deposits revealed the most complex superposition of clearly different shell-rich deposits. One large block sample covering the full sequence of these shell midden layers was collected in the West profile (Fig. 2) and resulted in four thin sections (PSB913.B1, B2, D1 and D2).

After drying, the samples were impregnated using a three-component synthetic resin mix (polyester resin, styrene and catalyst) at the facilities of the Instituto Internacional de Investigaciones Prehistoricas de Cantabria (IIIPC) and the Departamento de Ingenierias Quimica y Biomolecular, both at the University of Cantabria (UC) (Santander, Spain). Once totally consolidated, the blocks were cut into smaller slabs at the Departamento de Ciencia y Ingenieria del 
Table 3 Description and interpretation of the microfacies types identified in Poças de São Bento thin sections and correspondence, when existent, with $\mathrm{mF}$ types at Cabeço da Amoreira (Aldeias and Bicho 2016)

\begin{tabular}{lll}
\hline Microfacies type $\quad$ Major characteristics & $\begin{array}{l}\text { Corresponding Genetic interpretation } \\
\mathrm{mF} \text { at Cabeço da } \\
\text { Amoreira }\end{array}$ \\
& Amon
\end{tabular}

\begin{tabular}{|c|c|c|c|}
\hline $\begin{array}{l}\text { 1, Unsorted sand with } \\
\text { clay }\end{array}$ & $\begin{array}{l}\text { Unsorted sand and organo-mineral microaggregates of variable } \\
\text { sizes between the grains as well as partial coatings in the } \\
\text { coarser grains. }\end{array}$ & - & Ap2-horizon. Recent ploughing activity \\
\hline $\begin{array}{l}\text { 2, Sand and polymorphic } \\
\text { fom }\end{array}$ & $\begin{array}{l}\text { High amounts of pellets and welded aggregates of polymorphic } \\
\text { fom (30-40\%), distributed between and coating coarser sand } \\
\text { grains, forming a spongy microstructure. }\end{array}$ & - & A1-horizon. Middle Holocene Palaeosol \\
\hline $\begin{array}{l}\text { 2a, Sand and polymorphic } \\
\text { fom with few shells }\end{array}$ & $\begin{array}{l}\text { Same as type 2, but includes few shells }(5-10 \%) \text { strongly } \\
\text { decalcified. }\end{array}$ & - & $\begin{array}{l}\text { Surficial shell midden disturbed by pedogenic } \\
\text { activity and post-Mesolithic admixture. }\end{array}$ \\
\hline $\begin{array}{l}\text { 3, matrix-supported shells } \\
\text { - 3a, Coarse } \\
\text { heterogeneous }\end{array}$ & $\begin{array}{l}\text { Frequent shell fragments ( } 30 \%) \text {, charcoal, bone, fishbone and } \\
\text { char aggregates, all chaotically distributed. Heterogeneous } \\
\text { micromass: moderate to strong secondary micritic infillings, } \\
\text { organic silt particles and micro-charcoal between coarse } \\
\text { components and coating the surface of coarser components. }\end{array}$ & 2,4 & $\begin{array}{l}\text { Anthropogenic reworking of activity debris } \\
\text { (shellfish and other plant and animal } \\
\text { processing refuse) by dumping or raking } \\
\text { out. }\end{array}$ \\
\hline
\end{tabular}
Abundant highly birefringent microcrystals, presumably of calcite and sericite, resulting from secondary precipitation and feldspar alteration, respectively. Occasional rounded pebbles of calcareous rocks exposed to high temperatures (calcination and cracks) and quartz.

3 matrix-supported shells. Common shell fragments (20\%). Mineral sand and silt grains are Sub-type 3b, Coarse the dominant coarse components and very rare, fine sand inorganic sized charcoal and fewer bone. Scarce micromass (5-10\%) mainly calcitic, with little organic silt, forming coatings and microaggregates between coarse components. Localised micritic cementations, coatings and hypocoatings increase in relation to $\mathrm{mF}$ type $3 \mathrm{a}$.

4, Horizontally oriented Common to frequent shells $(30-40 \%)$ sub-horizontally oriented, 3 shells organised in stringers of interconnected shells, overall still matrix-supported. Most shells exhibit burning alterations and in situ crushing. Some shells display calcitic pendants. Charcoal, fishbone and char are also present in this $\mathrm{mF}$, along with occasional medium-sand size clay aggregates. The micromass and geogenic components are similar to $\mathrm{mF}$ type 3a.
5 , shell-supported sediments. Sub type $5 \mathrm{a}$, Interconnected shells

Practically all shells and some quartz grains exhibit calcitic pendants. High porosity $(20-30 \%)$, characterised by packing voids. Occasional scattered charcoals (5-10\%), several fish bones in a cluster and rarer isolated fragments. Clayey aggregates occur concentrated at the bottom of the deposits. Lenticular structures 2-4 mm thick of well-sorted, medium sized sand between the shells. Micromass is extremely rare and consists mainly of microcharcoal and microaggregates of organic and micritic composition.

\section{5 , shell-supported sediments. Sub-type $5 \mathrm{~b}$, Coarse wood} charcoal

6, Silty sands

6a, Silty sands with few shells

7, Calcitic cement
Coarse wood charcoal and shells, in a ratio of 50/50 are the main components. Phosphatic nodules (5\%) concentrated in clusters, probably result of decayed plant material.

Single grains of silty sand clast-supported sand and domains of $5 \mathrm{~b}$ complete micritic infillings of the space between sand grains.

Differs from $\mathrm{mF}$ type 6 solely by the presence of few or very few $5 \mathrm{a}$ shells (5-10\%) and rarer fine-sand-sized charcoal, without any orientation pattern.

Strong cementation by secondary calcite (micrite, needle fibre calcite and alveolar septal calcite) that infills the void space between the components almost completely (10\% void space).
Anthropogenic reworking of (mainly) shellfish refuse by dumping or rake out.

Trampled occupation surface.

Shell and debris tossing activity

Charcoal and shells tossing

Pleistocene/Holocene sand cover

Dispersed shells in the sand by processes related to the active layer and reworked downwards by bioturbation $1 b$

Carbonate cementation by secondary calcite (micrite and needle fibre calcite)
Terreno y de los Materiales (DCITYM-UC) in order to create a regular surface, suitable for thin section production. The resulting slabs were mailed to Earthslides
(Cambridgeshire, UK), which produced $110 \times 76$ and $75 \times 50 \mathrm{~mm}$ thin sections with the standard sample thickness of $30 \mu \mathrm{m}$, covered with a cover slip. 



A total of 17 thin sections were produced and digitally scanned using a flatbed scanner (Arpin et al. 2002), in normal and dark field modes (Goldberg and Aldeias 2016), for observations at normal scale and smaller magnifications. The 
4 Fig. 3 Representative microphotographs of the microfacies types at Poças de São Bento. All in PPL. All scales are $1 \mathrm{~mm}$. a mF type 1, sand with clay. $\mathbf{b} \mathrm{mF}$ type 2 , sand and polymorphic fine organic matter. c $\mathrm{mF}$ type $2 \mathrm{a}$, sand and polymorphic fine organic matter with few shells. $\mathbf{d}$ $\mathrm{mF}$ type 3, matrix-supported shells, subtype $3 \mathrm{a}$, coarse heterogeneous. $f b$ fishbone. e $\mathrm{mF}$ type 3 , matrix-supported shells, subtype $3 \mathrm{~b}$, coarse inorganic. f $\mathrm{mF}$ type 4 , horizontally oriented shells. $\mathrm{g} \mathrm{mF}$ type 5 , matrixsupported shells, subtype 5a, interconnected shells; note larger fragments of Scrobicularia plana shells. $\mathbf{h} \mathrm{mF}$ type 5, matrix-supported shells, subtype $5 \mathrm{~b}$, charcoal and shells. i $\mathrm{mF}$ type 6 , silty sands; note greyish zones corresponding to micritic infillings. $\mathbf{j} \mathrm{mF}$ type $6 \mathrm{a}$, silty sand with few shells; note char aggregate (char) and nearly complete Cerastoderma edule shell

optical examination was carried out using petrographic microscopes that allowed magnifications from $\times 20$ to $\times 400$ in plane- (PPL) and cross-polarised (XPL) light. The systematic micromorphological descriptions followed the terminology established by Stoops (2003) and Courty et al. (1989).

\section{Results}

\section{Sedimentary components}

The main sedimentary components observed in thin section are listed in Table 2, where detailed descriptions and brief genetic interpretations are also provided. Geogenic components are silt and sand mineral grains and few quartz, arkosic and calcareous pebbles. Silt and sand grains are mainly composed of medium to well-rounded quartz and feldspars, consistent with those observed from the Pleistocene/Holocene sand cover on which the shell midden rests. The pebbles are generally considered allochthonous, as they are not observed in the sand cover, and their presence is restricted to shell-rich anthropogenic sediments. These are, therefore, interpreted as anthropogenic inputs to the site.

Other anthropogenic-derived components comprise shells of peppery furrow (Scrobicularia plana), widely dominant, and the less frequent common cockle (Cerastoderma edule) (Fig. 3). Other components directly associated with human occupation include bone, particularly fishbone, sometimes with optical signs of burning (orange-reddish colour and loss of birefringence), wood charcoal and char aggregates (Fig. 3). Char aggregates, opaque masses with typical vesicles and cracks resulting from dehydration, are often attached to charcoals, with distinguishable carbonised cellular structure of the wood, which suggest that they correspond to charred plant-derived secretions, namely resin (Fig. 4a). The carpological analysis recovered charred and calcified insect excrements and also charred fungi anatomical parts (sclerotia) from anthropogenic sediments, which were considered to be ancient, possibly as result of exploitation of conifer wood, namely dead wood (López-Dóriga 2016). Our study corroborates the hypothesis, since we can observe, in thin section, common micritic faecal pellets (Fig. 4b), equally charred sclerotia (Fig. 4c) and calcified fungal filaments (hyphae) (Fig. 4d, e), that can be linked to the afore mentioned macrobotanical elements. Some loose phytoliths were observed, in association with highly organic micromass (Fig. 4f, g), rich in dusty charcoal and secondary micrite, particularly common in thin section PSB108 (as seen in Fig. 4d). All these components are finely mixed with the organic micromass of anthropogenic sediments (Fig. 4). The rare presence of small clay aggregates and isolated foraminifera and ostracods in shell-rich sediments is regarded as unintentional by-products of shellfish gathering in estuarine marshes of the River Sado.

\section{Microfacies}

The most discriminating factor for microfacies (henceforth, $\mathrm{mF}$ ) types identification at Poças de São Bento sediments were the relative abundance of shells and their organisation and orientation patterns. The different $\mathrm{mF}$ types broadly coincide with the stratigraphic units visible in the field. However, different geometric patterns, only observed in thin section, can be clearly distinguished within the shell midden layers and associated with specific human activities. A total of seven main $\mathrm{mF}$ types were identified in the thin sections from Poças de São Bento, with several subtypes. Table 3 summarises the major characteristics of each $\mathrm{mF}$ type, and representative microphotographs of each one can be found in Fig. 4. Some significant aspects for the interpretation of the formation processes of each $\mathrm{mF}$ type will be highlighted below. Detailed descriptions of each $\mathrm{mF}$ type are supplied in the Appendix.

Microfacies type 1 corresponds, mostly, to intensive agriculture practices carried out in recent decades, which involved remobilisation of sediments from elsewhere by means of heavy machinery. Therefore, we will not take $\mathrm{mF}$ type 1 into further consideration regarding the prehistoric occupations of the site.

Microfacies type 2 is discriminated by the micromass composed of polymorphic fine organic matter (henceforth, polymorphic fom), which is plant material decayed by the action of soil fauna in situ (Buurman and Jongmans 2005; Wilson and Righi 2010). Polymorphic fom generates pellets, more or less welded in aggregates (sensu Buurman et al. 2005) (Fig. 3b). We can distinguish a subtype, $\mathrm{mF}$ type $2 \mathrm{a}$, that includes few shells showing marked dissolution features.

Microfacies type 3, matrix-supported shells, has common (25\%) to frequent (30\%) shells, but they are not the dominant component, not in contact with each other and lack any orientation pattern. Secondary calcium carbonate occurs here in the form of micritic infillings and coatings. Interestingly, foraminifera specimens were spotted only in the two subtypes of this 

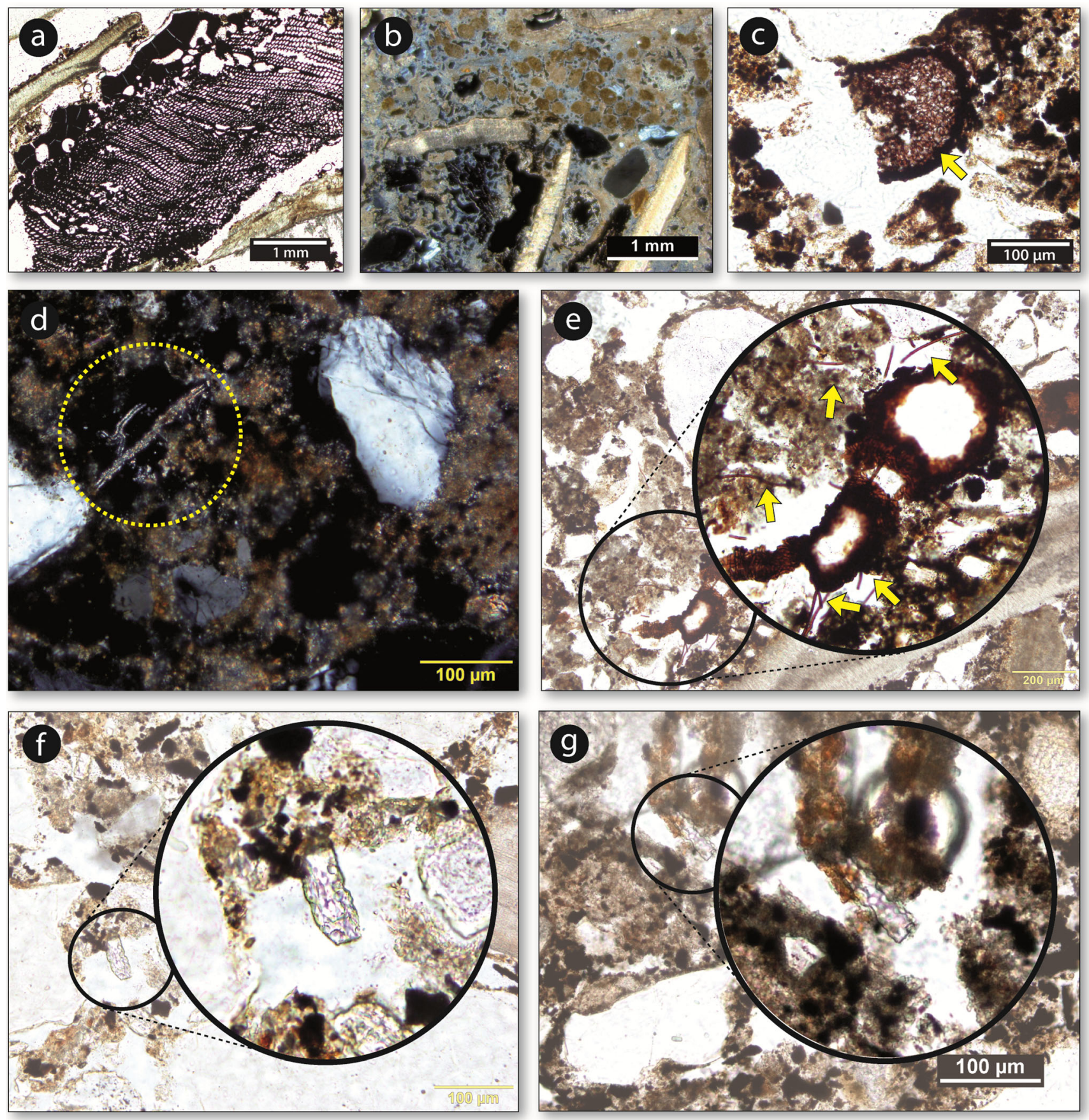

Fig. 4 Biogenic components of shell-rich anthropogenic sediments. a Wood charcoal and char aggregate from sample PSB913; note the carbonised cellular structure still preserved as charcoal; attached to it, note the amorphous mass with the vesicles (after air bubbles) and dehydration cracks typical of charred fats; in this case, most likely secretions such as resin, from the plant itself. PPL. Scale $1 \mathrm{~mm}$. b Example of calcitic faecal pellets (concentrated at the top) in an also calcitic matrix,

a needle fibre cement, from sample PSB108. XPL. c Charred sclerotia (yellow arrow) from sample PSB108. XPL. Scale: $100 \mu \mathrm{m}$. d Calcified filaments (dashed circle), with the inner hollow after the fungal hyphae degradation from sample PSB108. XPL. e Example of not charred or calcified fungal material, with detail of fungal hyphae, from sample PSB108. XPL. Scale: $200 \mu \mathrm{m}$. f, g Examples of phytoliths, possibly with signs of alteration, from sample PSB108. PPL. Both scales are $100 \mu \mathrm{m}$

$\mathrm{mF}$ type. These subtypes are: (a) $\mathrm{mF}$ type $3 \mathrm{a}$, with shells, charcoal, bone, fishbone and char aggregates, all chaotically distributed (Fig. 3d), and rounded pebbles of calcareous rocks that were exposed to high temperatures (calcination and cracks); (b) $\mathrm{mF}$ type $3 \mathrm{~b}$ is distinguished by slightly lower abundance of anthropogenic coponents such as shell 


\section{PSB913.B1}
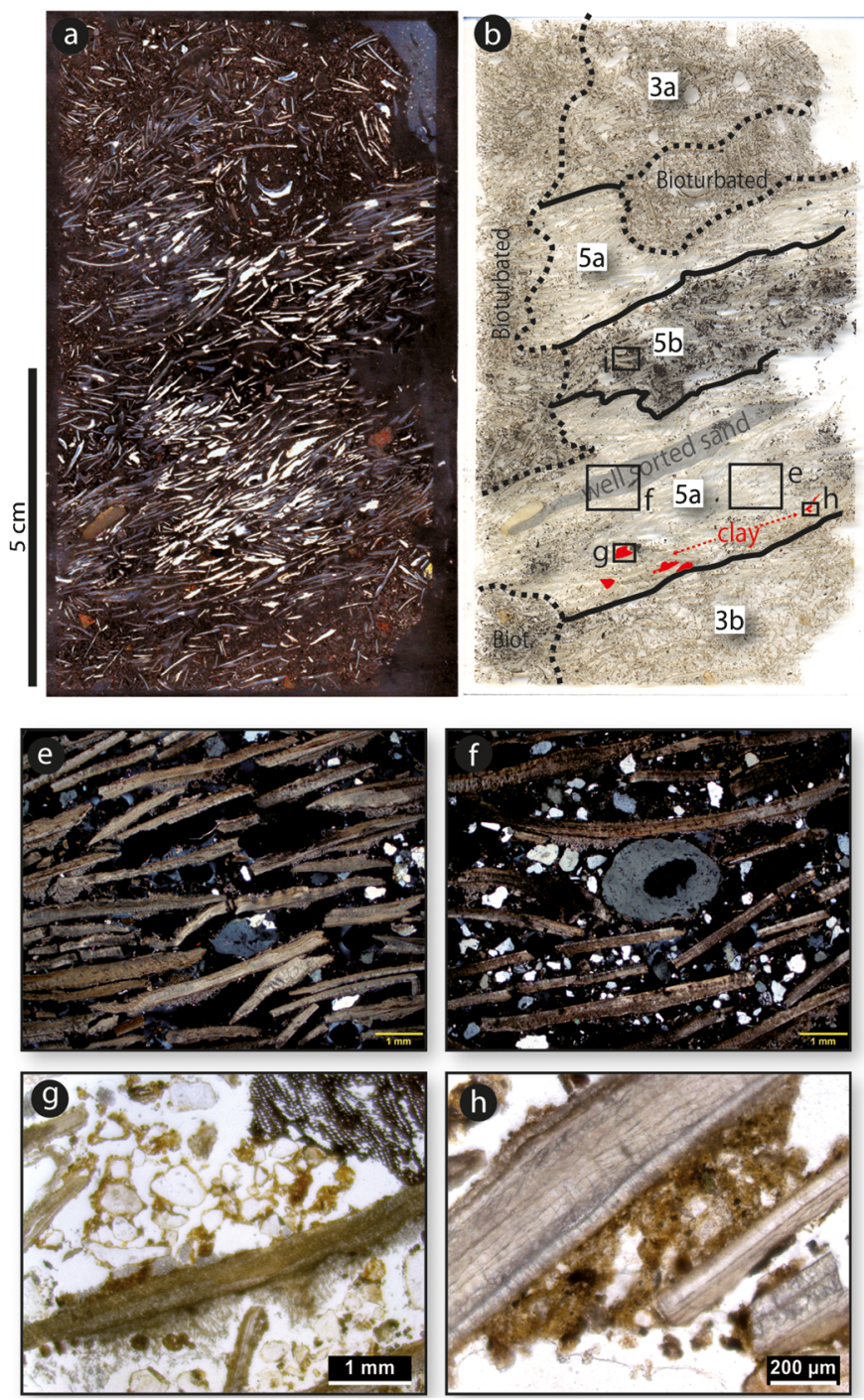

Fig. 5 Shell supported sediments: components and internal organisation. a Dark field scan of thin section 913.B1; note the superposition of different tossing events corresponding to mf types $5 \mathrm{a}$ and $5 \mathrm{~b}$ and circular/crescent fabrics in bioturbated areas. b Same at normal light scan, with indication of microfacies and further annotations; letters by the squares indicate the corresponding microphotograph below. c Dark field scan of thin section 913.D1; note the fishbones held together highlighted in orange (detail in k); note the presence of several orientation patterns of the shells and circular/crescent fabrics in bioturbated areas. d Same at normal light scan, with indication of microfacies and further annotations;

fragments (20\%) charcoal and bone and increasing secondary micrite.

In $\mathrm{mF}$ type 4 , the shells follow a sub-horizontal orientation pattern, organised in discrete stringers of interconnected shells, which are overall still matrix-supported. The shells show alterations induced by heating (brownish colour, loss of birefringence, as well as fissures parallel to the growth lines), according to archaeological and experimental evidence after Villagran (2014a) and

\section{PSB913.D1}
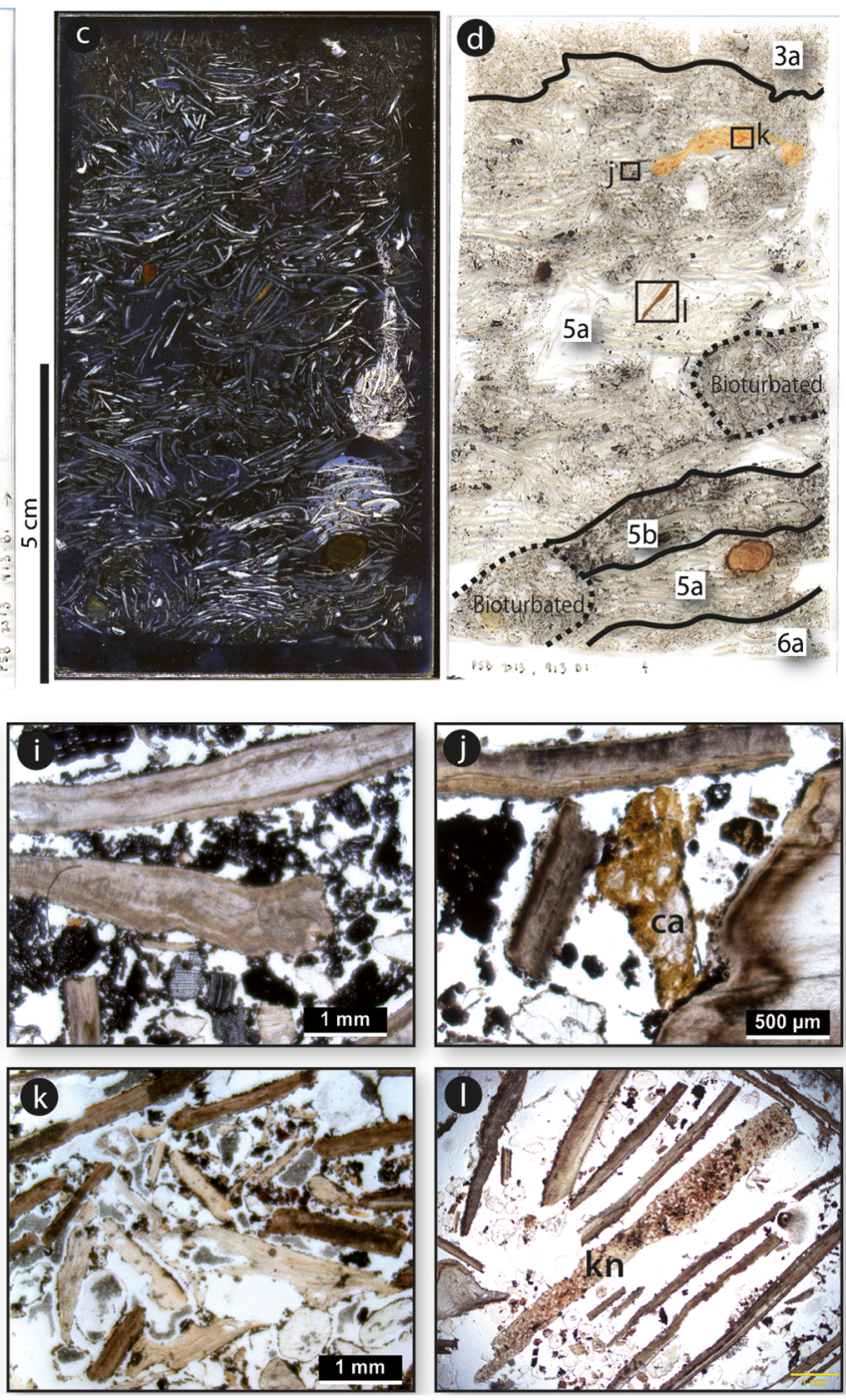

the letter in the squares indicates the corresponding microphotograph below. e Detail of sub-horizontally oriented shells in $\mathrm{mf} 5 \mathrm{a}$, note the lack of further components, XPL, scale: $1 \mathrm{~mm}$. f Detail of the well-sorted medium sand lens, XPL, scale: $1 \mathrm{~mm}$. $\mathbf{g}$, $\mathbf{h}$ Two aspects of clay, coating and forming bridges between coarser components, PPL. $\mathbf{i}$ detail of $\mathrm{mf}$ type $5 \mathrm{~b}$, note the presence of exclusively wood charcoal and shells. $\mathbf{j}$ Examples of clay aggregate (ca), PPL. $\mathbf{k}$ Detail of the cluster of fish bones (lighter components), PPL. I Detail of the possible knapping residue (kn), PPL, scale: $1 \mathrm{~mm}$

Aldeias et al. (2016). The shells also exhibit vertical fractures interpreted as in situ breakage i.e. the shells were crushed but remained in their position. These millimetrethick stringers were not identified in the field, and the total thickness of the $\mathrm{mF}$ in thin sections is $<2 \mathrm{~cm}$.

Microfacies type 5 corresponds to deposits where shells are the dominant component, normally interconnected, without a preferential orientation pattern. However, the deposits corresponding to this $\mathrm{mF}$ follow a slightly oblique general 
$\mathrm{mF} 3 \mathrm{a}$, coarse heterogeneous
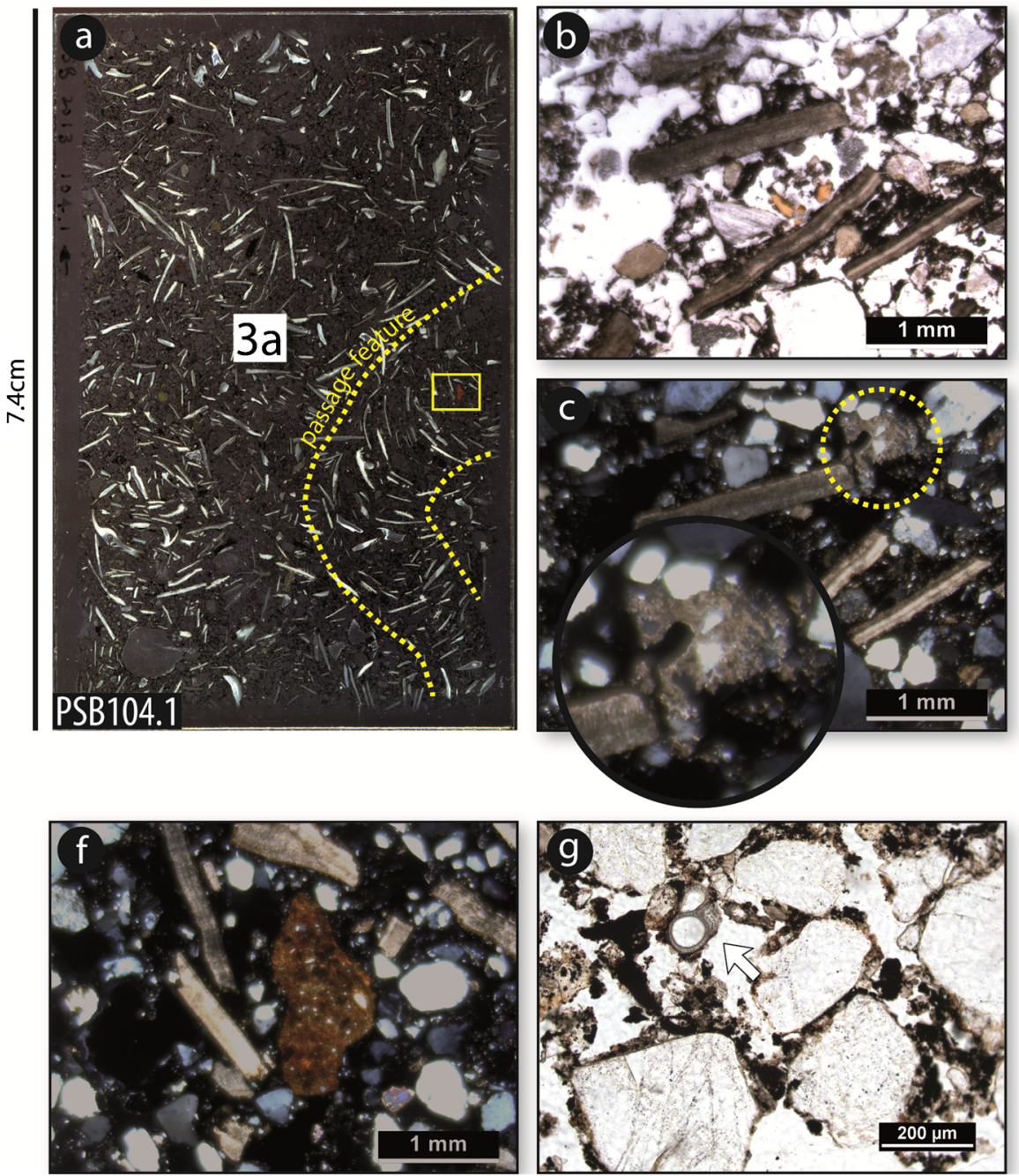

matter, compared to $\mathrm{mF} 3 \mathrm{a}(\mathbf{b})$. e Same as $\mathbf{d}$, XPL; note the generally calcitic micromass (crystallitic b-fabric), with strong birefringence, and calcitic hypocoating (rhizolith, dashed circle). f Detail of pottery fragment biologically reworked into $\mathrm{mF} 3 \mathrm{a}$ sediments, as indicated by its microcontextual position inside the passage feature, XPL. g A foraminifer (white arrow) in $\mathrm{mF}$ 3a sediments, PPL, scale: $200 \mu \mathrm{m}$. h Another foraminifer (white arrow) in $\mathrm{mF} 3 \mathrm{~b}$ sediments, PPL, scale: $200 \mu \mathrm{m}$

Microfacies type 6 consists of single grains of clastsupported silty sand with domains of complete micritic infillings. A subtype, $\mathrm{mF}$ type $6 \mathrm{a}$, differs from $\mathrm{mF}$ type 6 solely by the presence of few or very few shells and rarer fine sand sized charcoals.

Microfacies type 7 corresponded, in the field, to areas varying from $2 \mathrm{~cm}$ nodules to wide patches strongly cementated by secondary calcite that, as seen in thin section, infills the void space. The deposits corresponding to $\mathrm{mF}$ type 7 are in the base of shell midden layers, in the same situation as reported at Cabeço da Amoreira (Aldeias and Bicho 2016). 

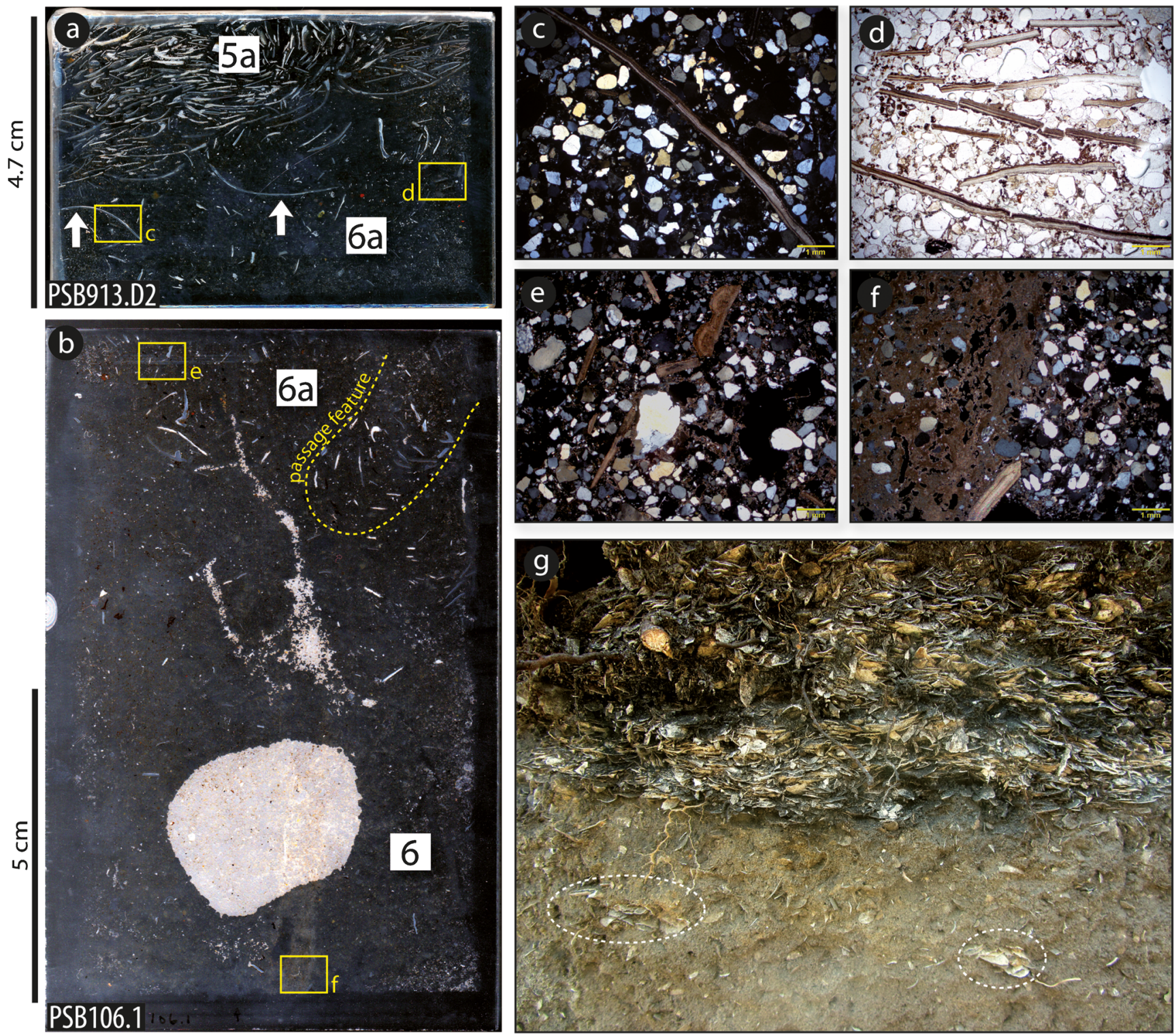

Fig. 7 The sand cover substrate. a Dark field scan of thin section PSB104.1, showing the contact between $\mathrm{mF}$ types $6 \mathrm{a}$, silty sand with few shells, and 5a, interconnected shells; note the complete sections of $S$. plana (white arrow) surrounded by $\mathrm{mF} 6 \mathrm{~s}$ sediments, in horizontal position. The letters by the squares indicate the corresponding microphotograph to the right. b Dark field scan of thin section PSB106.1, with indicator of post-depositional movements of shells into the sand; note passage feature (dashed line) with shells in a crescent organisation pattern. The letters by the squares indicate the corresponding microphotograph to the right. $\mathbf{c}$ Microphotograph where it is clear that the complete valve of $S$. plana is surrounded by sand from the sand cover
(mF type 6a), XPL, scale: $1 \mathrm{~mm}$. $\mathbf{d}$ Group of shells in $\mathrm{mF}$ 6a showing in situ cracking, PPL, scale: $1 \mathrm{~mm}$. e Shell fragments in sub-vertical position, not clearly associated with bioturbation, XPL, scale: $1 \mathrm{~mm}$. $\mathbf{f}$ Detail of micritic infilling of bioturbation feature, with a shell fragment in its limits, probably associated with biological reworking, XPL, scale: $1 \mathrm{~mm}$. g Field photograph of Area 9 south profile, with the $\mathrm{mF}$ type 5, shell supported sediments, deposit overlying $\mathrm{mF}$ 6a sands; note the subhorizontally oriented shells (dashed ellipses), laying a few centimetres below the shell midden deposit, surrounded by possibly reworked sands from the aeolian basal sands

(Fig. 2c). In the shell-rich sediments at Poças de São Bento, observing the micromorphological thin sections at $1: 1$ scale, it is possible to discern more accurately the extent to which these disturbances affect the stratigraphic record and track post-depositional movements of archaeological material. At the microscopic scale, postdepositional processes are readily identifiable, which
The archaeological stratigraphy at Poças de São Bento is badly affected by post-depositional alterations. Recent ploughing, small mammals' burrows, biological (root and soil fauna) channels and localised concretions are some of the most striking disturbances visible in the field 

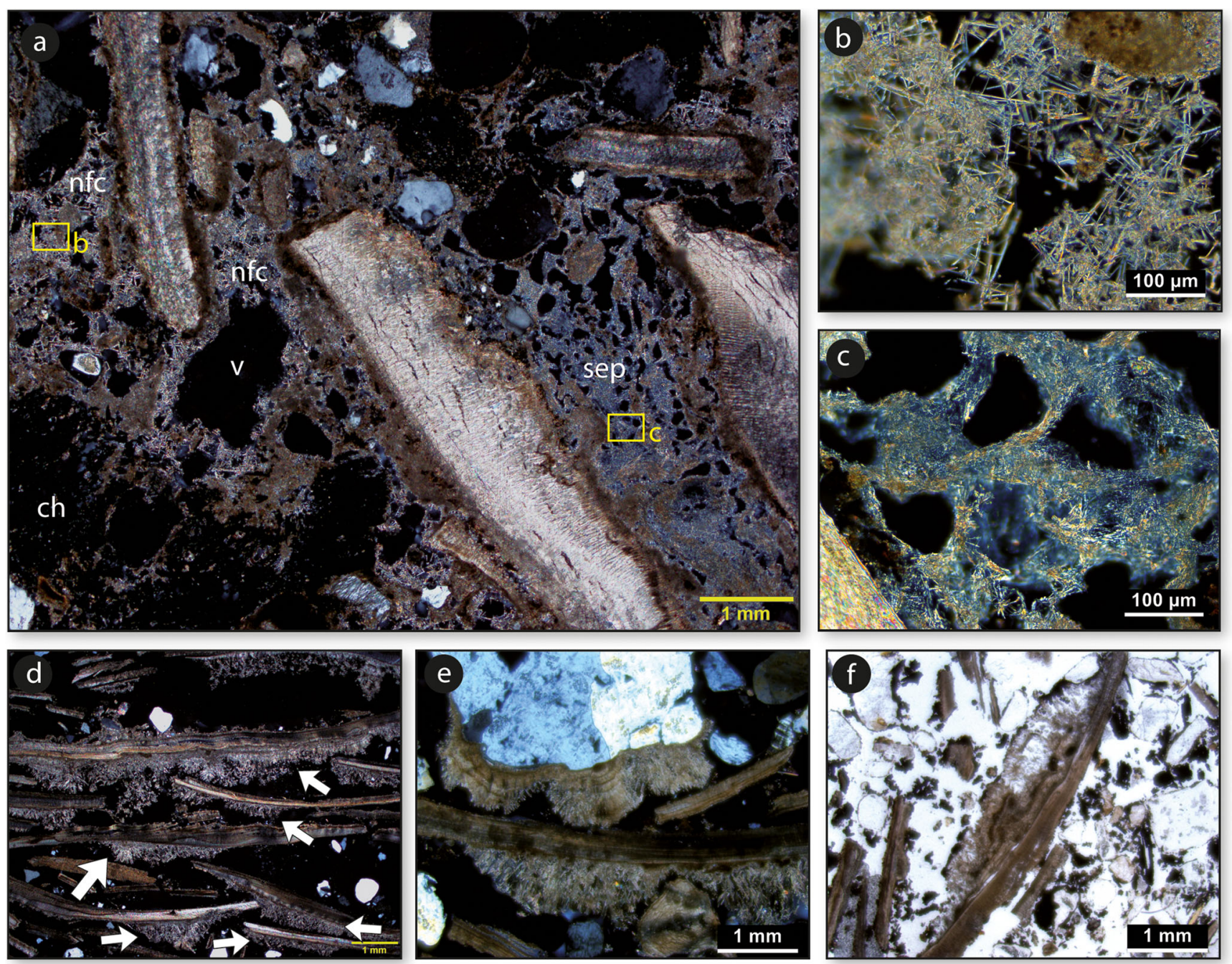

Fig. $8 \mathrm{mF}$ type 7, calcitic matrix, and post-depositional crystallitic features. a Representative microphotograph of $\mathrm{mF}$ type 7 from thin section PSB510; note the several types of secondary calcite filling the void space $(v)$ between shells and charcoal $(\mathrm{ch})$. The letters by the squares indicate the corresponding microphotograph to the right. b Detail of needle fibre calcite, XPL. $\mathbf{c}$ Detail of alveolar septal fabric calcite, XPL. d Example of calcitic pendants below interconnected shells of $\mathrm{mF} 5 \mathrm{a}$ in sample PSB913.B1, XPL, scale: $1 \mathrm{~mm}$. e Calcitic pendants at higher magnification; note the elaborate example under a quartz grain, where the several layers representing different phases of crystal formation are visible, XPL. f Example of disturbed shells, as indicated by the calcitic pendant not in the original formation position, PPL allows the preservation conditions of the anthropogenic materials to be addressed, a fundamental aspect of archaeological interpretation (Goldberg and Berna 2010). The post-depositional processes can be divided into two groups based on their implications for the integrity of the archaeological record at the site; these are crystallitic features and mechanical disturbance.

\section{Crystallitic features}

Crystallitic features result from calcium carbonate dissolution and reprecipitation. In the setting of the human settlement at Poças de São Bento, the presence of calcium is mostly due to the anthropogenic input of shells. Moreover, there are carbonated rocks in the broader geological environment (Miocene sediments that have undergone pedogenic carbonation) (Pimentel and Azevêdo 1994), exposed in some points of the slopes of the Sado Valley. Some of these rocks were also anthropogenically introduced to Poças de São Bento alongside the incorporation of shells.

Dissolution is an important process affecting the shells at the site. In $\mathrm{mF} 2 \mathrm{a}$, sand and polymorphic fom with few shells, this process is observed in the majority of shells, which overall present intense carbonate loss. Microfacies type 7, calcitic cement, can be interpreted as the result, also post-depositional, of this process: The carbonates secondarily precipitated in certain zones, originating cemented areas of shell-rich deposits, normally at the bottom of the deposits. Cementation of basal shell midden 

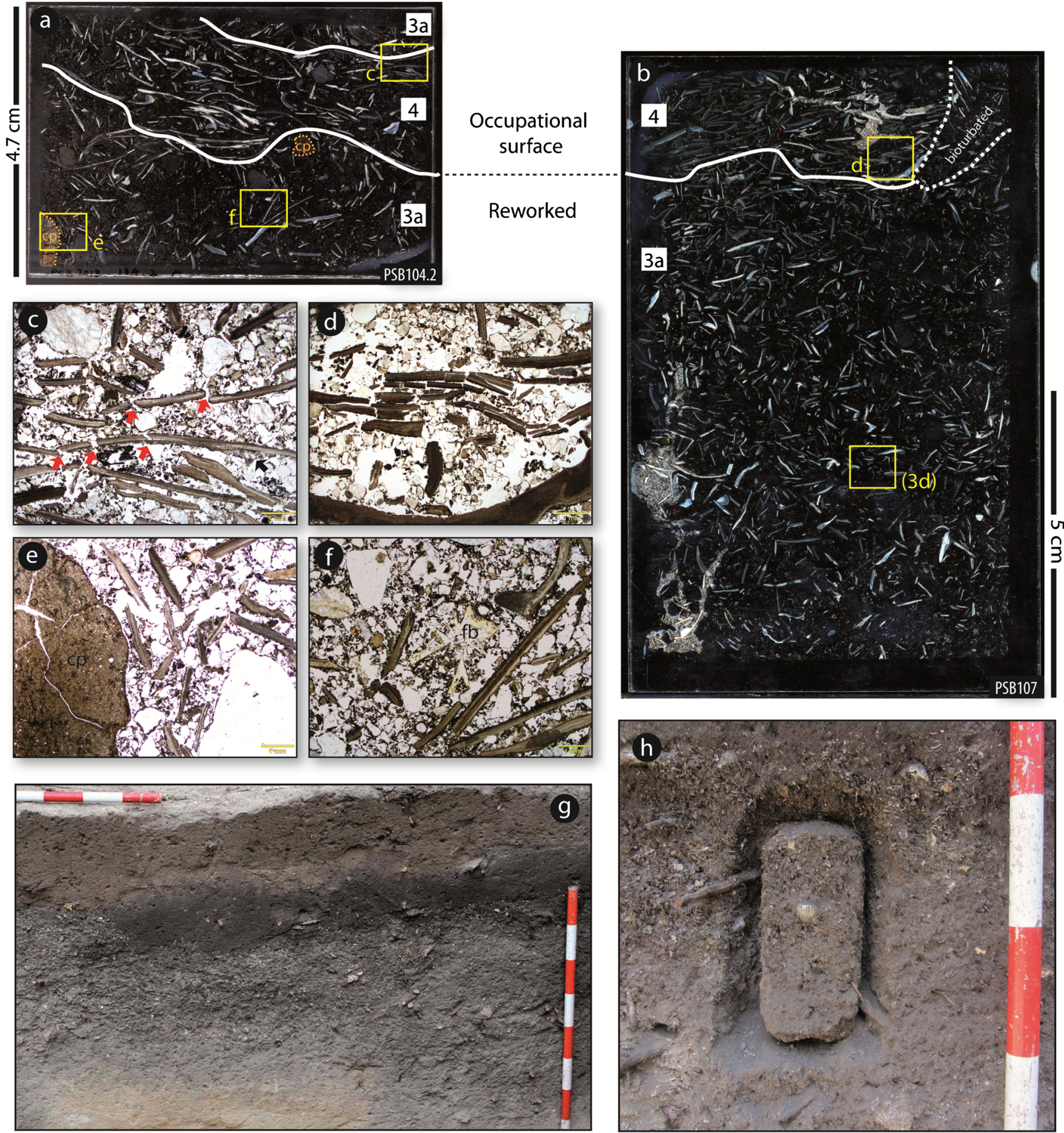

Fig. 9 Superposition of microfacies of anthropogenic sediments in Area $1 ; \mathrm{mF}$ type 4 , horizontally oriented shells, overlying $\mathrm{mF}$ type $3 \mathrm{a}$, coarse heterogeneous. a Dark field scan of thin section PSB104.2, with $\mathrm{mF}$ contacts marked (white lines); note the calcareous pebbles $(c p)$ in $\mathrm{mF}$ $3 \mathrm{a}$. The letters by the squares indicate the corresponding microphotograph below. b Dark field scan of thin section PSB107, with $\mathrm{mF}$ contacts marked (white lines). The letters by the squares indicate the corresponding microphotograph below. c, d Detail of horizontally oriented shells in $\mathrm{mF} 4$; note in situ cracking (red arrows), PPL, both scales: $1 \mathrm{~mm}$. e Detail of calcareous pebble; note the cracks, possibly due to exposure to heating, PPL, scale: $1 \mathrm{~mm}$. f Detail of $\mathrm{mf} 3 \mathrm{a}$, coarse heterogeneous; note the fish vertebra (fb), PPL, scale: $1 \mathrm{~mm}$. g Aspect of the shell midden layer in Area 9 before the micromorphological sampling; note the homogeneity. h Closer view of the same profile during collection of the sample PSB107; mf type 4 is not perceptible (compare with the resulting thin section above) deposits due to dissolution of the overlying shells by rainwater was noticed by Roche (1966) in Moita do
Sebastião, another shell mound in the Muge Valley, near Cabeço da Amoreira. Aldeias and Bicho (2016) also 
described the phenomenon at the latter. The cement in $\mathrm{mF}$ type 7, calcitic cement, is formed by several types of precipitates, of which micrite is most abundant (30\%), coating irregularly the components' surfaces and forming closed vughs. Micritic infillings and hypocoatings are also abundant in $\mathrm{mF}$ type 3, matrix-supported shells, particularly 3b, coarse inorganic (Fig. 6c, e) although without hardening these deposits, and constituting the very expressive, sometimes complete infillings of bioturbation features in the sandy $\mathrm{mF}$ types 6 and 6a (Fig. 7e).

Needle-fibre calcite is exclusively seen and very common in $\mathrm{mF}$ type 7 , calcitic cement, formed by thin (0.5$2 \mu \mathrm{m}$ wide) and very long (up to $100 \mu \mathrm{m}$ ), randomly oriented crystals forming a meshwork pattern, superimposing surfaces of voids in the micritic infilling (Fig. 8a, b). Another common type of cement at $\mathrm{mF}$ type 7 is the so-called alveolar septal fabric (Scholle and Ulmer-Scholle 2003) (Fig. 8c), forming narrow, curved septa consisting of bundles of even finer calcite needles $(>0.5 \mu \mathrm{m}$ wide and $<2 \mu \mathrm{m}$ long), barely perceptible under the petrographic microscope. Similar crystals have been interpreted as reproducing fungal mycelial shapes (Scholle and UlmerScholle 2003) and attesting to a significant fungal presence in the deposit. Another element both in the cemented layers and, to a lesser extent, overlying shell-rich deposits are calcified filaments (Fig. 4d), threadlike structures corresponding to fungal hyphae encrusted with minute calcium carbonate crystals (Durand et al. 2010). Calcified roots or rhizoliths (Durand et al. 2010) occur in both cemented and non-cemented deposits (Fig. 6e). These post-depositional, calcitic features reach centimetre-thick dimensions in the cover sand deposits underlying the shell midden (Figs. 2c and 7f).

Another very common secondary calcite feature, unrelated to cemented deposits or biogenically induced calcite, is the aforementioned pendants. These structures are formed in meteoric vadose areas i.e. above the water table, where there is enough void space for water drops to hang from the underside of the grains (Scholle and UlmerScholle 2003; Flügel 2004). At Poças de São Bento, the pendants, reproducing the drop shape, consist of alternating laminae, roughly parallel to the bottom surface of shells on which they formed. The laminae exhibit differences in colour, from limpid to brownish, depending on the amount of organic matter (Durand et al. 2010). They can become quite irregular in the outermost surfaces, because of varying crystal morphologies of each laminae, ranging from micritic to microsparitic and acicular calcite crystals, and overall are quite fibrous. The aggradation of repeated pendant layers (Fig. 8e, f) is common, forming fan-like structures, indicating several phases of partial water saturation of the deposits. Practically, all shells and some coarse sand/gravel grains in $\mathrm{mF}$ type $5 \mathrm{a}$, interconnected shells, exhibit pendants (Fig. 8d), and there are rare occurrences under some shells in $\mathrm{mF}$ type 4, horizontally oriented shells (Fig. 9c).

\section{Mechanical disturbances}

In thin section, it is possible to delimitate, with remarkable precision, the areas mechanically disturbed by soil fauna (mainly arthropods) that, while burrowing, rearranged the shells in crescent/circular patterns, forming passage features, easily recognised at normal scale analysis of thin sections (Figs. 5a, c, 6a, and 7b). Moreover, it is possible to affirm that shells in these areas have been disturbed because some of them exhibit shells with rotated pendants (Fig. 8f) i.e. pendants not in the original gravitational position, meaning that the shell was disturbed after the pendant formation. The degree of bioturbation at Poças de São Bento in the remobilization of archaeological material is an important issue. For instance, the secondary position of a pottery fragment, consistent with ages of $\mathrm{mF}$ type 2 deposits, downwards into Mesolithic $\mathrm{mF}$ type 3 a sediments was observed in thin section PSB104.1, inside one of these passage features (Fig. 6a, f). These features, easily recognisable for their two-dimensional geometry in thin section, are not always perceptible in the field.

\section{Discussion}

The recognition of microfacies enables the reconstruction of different human activities and behaviours behind the accumulation of shells and other anthropogenic debris at Poças de São Bento. Moreover, it provides precise information on natural processes during the site's occupation and how it might have been modified by post-depositional processes. Broader geological information available has provided relevant clues for the interpretation of human behaviour in the construction of shell middens at Poças de São Bento. In the next sections, we will address those questions, based on the geoarchaeological record studied with the mentioned methodologies.

\section{The sand cover substrate}

The interface between sterile dune sand and the first occupational deposits is difficult to pinpoint. There is no sharp contact from utterly "clean" sands, in terms of anthropogenic material, to shell-rich sediments. MF type 6, silty sands, corresponds to the lowermost and cleanest sands. The minute and extremely rare shell fragments in the $\mathrm{mF}$ appear to be post-depositionally displaced by root activity. This is supported by the microcontext of these 
fragments, characterised by micritic impregnations around roots (Fig. 7e, f).

In the overlying $\mathrm{mF} 6 \mathrm{a}$, silty sand with few shells, the number of shells progressively increases towards the contact with shell midden layers and reaches a relative abundance in thin section of 5-10\%, in the immediate $10-20 \mathrm{~cm}$ below the shell midden, in both Areas 1 and 9. These sediments exhibit a grey colour in the field, and the contact with the lowermost yellow sands is gradual and marked by macroscopically visible bioturbation features, such as root and insect channels. We attribute the grey colour to the precipitation of secondary carbonates, which are visible in thin section.

In sample PSB913 (Area 9), within 2-4 $\mathrm{cm}$ below the lower contact with the shell midden, $\mathrm{mF}$ 6a presents some remarkable aspects regarding shell positions. One is that the shell fragments are randomly oriented, many in vertical position, but not associated with bioturbation features that explain their presence as post-depositional. Thus, their presence here must have another origin (Fig. 7a, c, d, g). Aldeias and Bicho (2016) previously noted that shells in vertical position were most likely deposited together with the surrounding sediment (otherwise, if not supported by the sandy matrix, the shells would tend to fall to a more natural horizontal position) which suggests that these are reworked sands that already contained shells. Another interesting aspect in thin section is the case of two nearly complete sections of Scrobicularia plana valves in sub-horizontal position; these were also perceptible in the field, where sometimes, several horizontal shells, crushed in situ and surrounded by sand, were found. However, as noted above, these intact valves point to little transport. Given that the matrix is undoubtedly the same as the Pleistocene/Holocene cover sand, we interpret the first (upper) few centimetres of $\mathrm{mF}$ type $6 \mathrm{a}$ deposits, at least in Area 9, as an active layer i.e. a rather unstable sand surface, susceptible to particle movements. The shells in these surficial sands may have arrived by dispersion. So far, there is no field evidence of such deposits, so this remains open as a hypothesis for future work.

Dispersion of shells can result from many factors. Wind is an important natural agent in sandy settings, promoting surficial creep of silty-sand sized materials and rolling and saltation of coarser particles (French 2003; Courty et al. 1989), where shell fragments would be equally affected. Dispersion by human trampling is also a possibility that was taken into consideration for a similar $\mathrm{mF}$ type described at Cabeço da Amoreira (Aldeias and Bicho 2016). The fact that some horizontally oriented shells in these sands display in situ crushing (Fig. 7d), resembling those in $\mathrm{mF}$ type 4 , could mean that some trampling was reponsible for shell dispersion and incorporation in the surficial sand. Nevertheless, apart from the described microcontextual evidence of some shells in the surface having arrived with the sand by particle movements, in lower depths (from the first $2-4 \mathrm{~cm}$ downwards), bioturbation is considered the main agent for post-depositional migration of shells of $\mathrm{mF}$ 6a deposits. Bioturbation has long been considered a major factor in vertical displacements of archaeological material in sandy settings (Goudie 2017). The OSL date of $12 \pm 1$ ka seems to support this. The dated sample comes from the middle part of the $\sim 20 \mathrm{~cm}$ thick stratigraphic unit 912 (Area 9, see Fig. 1), containing shells, corresponding to $\mathrm{mF}$ type 6a. In sum, the date refers to a moment of sand accumulation and stabilisation at the end of the Pleistocene (see Table 1), thus incompatible with any human occupation so far identified at Poças de São Bento. With micromorphology, however, we can track more precisely the extent of movements by at least roots and insects (those of larger animals like rodents, mustelids or rabbits are clearly visible macroscopically). The recognition of such movements and microcontextual observations like those mentioned above (fragmented versus complete valves, organisation pattern and association or not with rhizoliths) indicate that some of the shells, in the first few $\mathrm{cm}$, were deposited with the matrix.

\section{Anthropogenic formation processes: human activities at Poças de São Bento}

The microfacies approach to the shell midden layers at Poças de São Bento allowed the discrimination of specific, intact characteristics of its internal microstratigraphy and the association of each one to anthropogenic actions, divided into three main types of activity. As already stated, very interesting and remarkable similarities were found with some of the $\mathrm{mF}$ types, corresponding to shell-rich deposits, described at the site of Cabeço da Amoreia (Aldeias and Bicho 2016). This site is a larger shell mound, forming an artificial hill perceptible in the landscape. It is one of a group of Mesolithic shell mounds known in the Muge Valley, part of the early Holocene palaeo-estuary of the Tagus River (for details, see Bicho et al. 2013, 2011), located approximately $100 \mathrm{~km}$ north of the Sado shell middens area (Fig. 2). Given the similarities in the $\mathrm{mF}$ between the two sites, an outcome with valuable broader implications, here, we follow the nomenclature proposed by Aldeias and Bicho (2016) for anthropogenic activities (see also Villagran et al. 2011). For a correlation of the $\mathrm{mF}$ types and their respective brief interpretation at Poças de São Bento, linked to $\mathrm{mF}$ types at Cabeço da Amoreira, see Table 3.

\section{Single tossing events}

Microfacies type 5, shell supported sediments, is thought to be the result of preserved single events of direct tossing of 
debris, mainly shells. These are often interconnected and parallel to each other, albeit not according to a single systematic orientation, and exhibit a low degree of fracturing. These deposits were identified in Area 9 and Area 5, although the latter was secondarily cemented. In thin section, features like fishbones maintained together (Fig. 5d, k) and 2-4 mm thick lens of well sorted medium-sand sized mineral grains (Fig. 5b, f) indicate little disturbance after deposition, thus possibly rapid burial. Clay coatings (pale yellow, stipple-speckled b-fabric) and interstitial clayey aggregates (Fig. 5g, h, j) contrast with the poorly sorted silt to coarse sand in the substrate, where clay is inexistent. For this reason, the well-sorted sand grains and the clay aggregates are interpreted as coming from a different source, possibly the estuarine marshes where shellfish was gathered using sediment-bearing techniques; it would suggest transport of the shellfish from the gathering place directly to the site of Poças de São Bento. This aspect reinforces the importance of the on-going sedimentological research on the Sado Valley infill, which is partially aimed at clarifying issues such as this. It is interesting to note that $\mathrm{mF} 5 \mathrm{a}$ is the only one where most of the shells exhibit well-developed calcitic pendants, sometimes very elaborate, indicating several events of partial water saturation (Fig. 8d, e, f).

Like in the $\mathrm{mF}$ type at Cabeço da Amoreira also interpreted as single tossing events (see Table 3), the shells in Poças de São Bento's mF type 5a show some in situ cracks. Although, at Poças de São Bento, these features are not as overwhelming as at Cabeço da Amoreira, where the shells follow only one consistent, sub-horizontal orientation pattern, and in situ cracks are abundant (see Figs. 4 and 5a in Aldeias and Bicho 2016), we argue that they similarly have suffered some trampling, but perhaps not repeatedly. A microfacies type at the recent shell midden of Túnel VII, Tierra del Fuego (Argentina), also with interconnected shells in sub-horizontal, oblique and sub-vertical orientation patterns, was interpreted as "tossing of discarded items on the hut outer perimeter where the Yamana used to deposit the waste of daily indoor activities" (Villagran et al. 2011). The characteristics of $\mathrm{mF}$ type 5a at Poças de São Bento resemble more closely this organisation pattern Aside from the differences in thickness between Túnel VII (up to $50 \mathrm{~cm}$ ) and Poças de São Bento $(10 \mathrm{~cm})$, and taking into account the evidence of the mentioned well preserved microcontextual arrangements, we

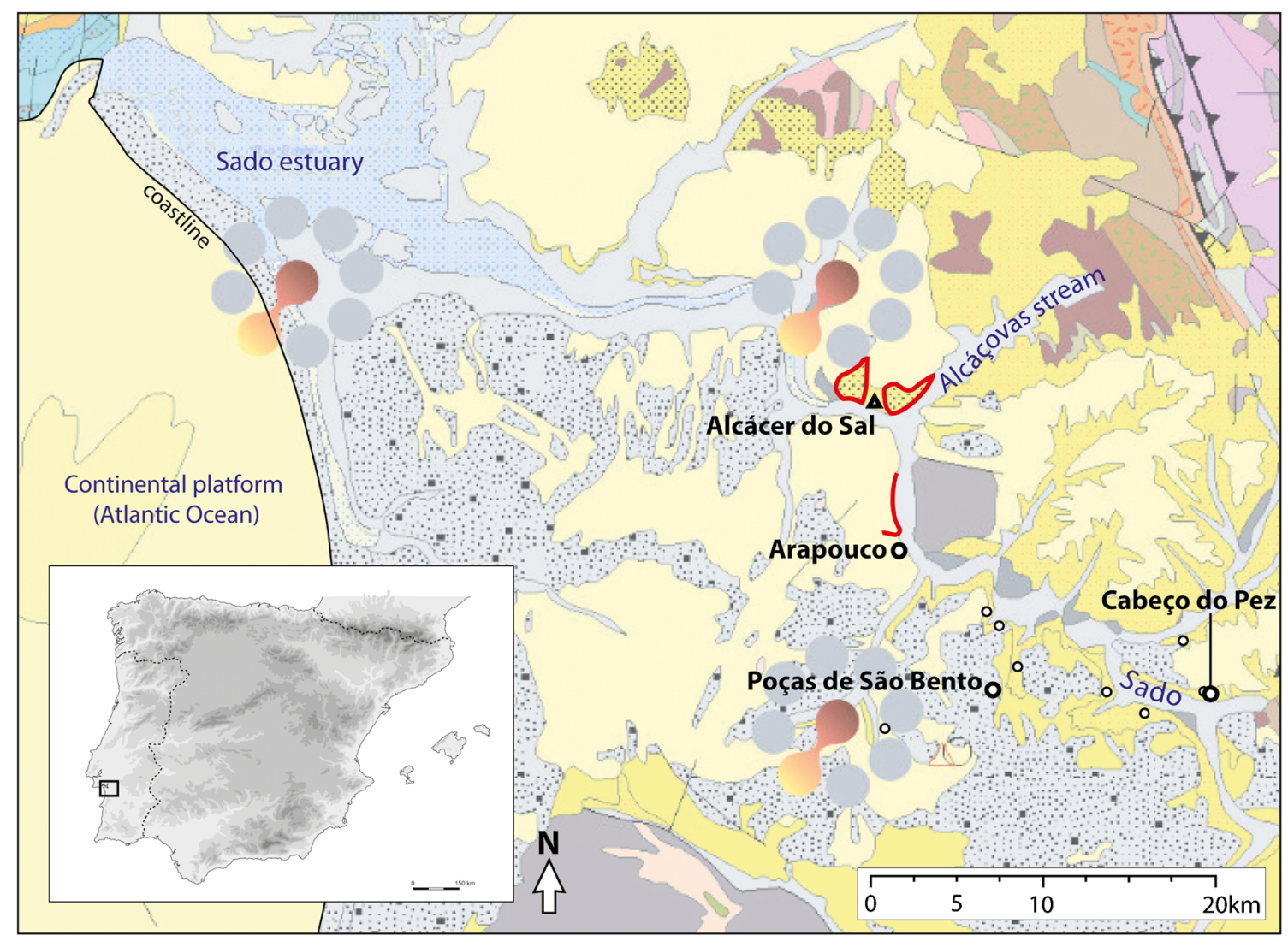

Fig. 10 Geologic map of the Sado shell middens area, with location of the town of Alcácer do Sal, Poças de São Bento, Arapouco, Cabeço do Pez and the other known shell midden sites (white dots). Note the outcrops of Miocene calcareous rocks mentioned in the geological cartography, delimited in red. Note the present day estuary. Geologic map source: Laboratório Nacional de Engenharia e Geologia, Carta geológica de Portugal 1:500,000, version available online 




Fig. 11 Hypothetical reconstruction of the events involved in the accumulation of the shell midden layers in Area 9, based on the four thin sections from sample PSB913 (to the left; see also Fig. 2b), with indication of $\mathrm{mF}$ type boundaries and assigned activities. a Plan view of the excavation of $\mathrm{mF} 5$ deposit (right side of the photo, mostly complete shells) and contact with the underlying $\mathrm{mF} 3 \mathrm{~b}$ deposit (left side of the photo, shells are fragmented and matrix-supported); note the diffuse perimeter of $\mathrm{mF} 5$ deposit, scale: $20 \mathrm{~cm}$. b Close-up on $\mathrm{mF} 5$ deposit; note the quite complete shells. c Close-up of the corresponding zone of the profile before sampling; note that only major events are clearly discernible in the field photo; scale at $20 \mathrm{~cm}$ may think of a similar deposit of discarded activity debris, in an area of the site not continuously occupied and probably covered shortly after deposition.

The interpretation of $\mathrm{mF}$ subtype $5 \mathrm{~b}$, coarse charcoal and shells, is revealed by the high porosity and the shells' orientation pattern, which suggests also a single tossing event, but of more selected material: Only coarse charcoals and shells, in equal proportion, seem to have been tossed. We may tentatively think of different activities as the origin of the selection of components. Perhaps, $\mathrm{mF} 5 \mathrm{a}$ components were generated from the processing and consumption of shells and fish, whereas $\mathrm{mF} 5 \mathrm{~b}$ could be the result of disposal of fire residues from a cooking structure e.g. roasting with fire on top of the shellfish in a cuvette and later removal of the charcoal, as proposed in one of the experiments by Aldeias et al. (2016). Furthermore, there are no micromorphological indicators that this is an in situ combustion event, such as heated substrate or ashes which should be preserved, given the basic $\mathrm{pH}$ provided by the shells. Microfacies $5 \mathrm{~b}$ was identified clearly in thin section $913 \mathrm{~B} 1$, with a thickness of $1.5 \mathrm{~cm}$, between two deposits corresponding to $\mathrm{mF}$ 5a (Figs. 2b and $5 \mathrm{~b}$ ), and there are other possible $\mathrm{mF} 5 \mathrm{~b}$ domains in lower PSB913D1 thin section (Fig. 5d). 
Based on the above, we argue that the shell supported sediments of $\mathrm{mF}$ type 5 correspond to the superposition of single tossing events, in primary position. When excavated, these deposits exhibit a maximum thickness of $\sim 10 \mathrm{~cm}$ and have irregular upper contacts (Fig. 2b), as well as irregular boundaries in plan view. Despite intense disturbance by roots, which complicates the visualisation of the original shape, this spatial geometry makes us think of extended deposits, although still spatially well delimited.

\section{Reworked anthropogenic deposits}

The microfacies approach allowed the recognition of anthropogenic shell-rich deposits that were not in primary position but had been reworked. These correspond to $\mathrm{mF}$ type 3, matrix-supported shells, which had two subtypes. Subtype 3a, coarse heterogeneous, contains randomly orientated and distributed shells, including several in vertical position, which, together with a high degree of fragmentation, suggests that they were deposited with the matrix that supports them. The randomly distributed charcoal and fishbones, indiscriminately burnt and unburnt ( $5 \mathrm{~b}$ and $8 \mathrm{f}$ ), also support this interpretation, in contrast with the concentrated distribution patterns of these types of remains in $\mathrm{mF}$ type $5 \mathrm{a}$. The high abundance of organic components in both coarse and fine fractions is related to animal and plant processing for consumption, here in secondary position.

In $\mathrm{mF}$ type $3 \mathrm{a}$, there are also geogenic components such as small calcareous pebbles, and these are equally interpreted as anthropogenic inputs, based on the fact that the lithologies do not occur in the local Pleistocene/ Holocene basal sand and that they are absent in other $\mathrm{mF}$ types. However, they occur in the broader geological region (Fig. 10) where calcareous rocks occur in Miocene outcrops in specific localities towards the bottom of the Sado Valley, that is, downstream from the site. It does not seem likely that they could have been brought to the site by a natural agent given the relief and distance. The clasts are too small $(0.5$ up to $\sim 5 \mathrm{~cm})$ to be suitable for any recognisable activity, leading to the exclusion of an intentional transport to the site. Indeed, there is no evidence of using them as raw material for lithic tools production, as there are for other allochthonous rocks (Pimentel et al. 2015). Instead, it is more likely that they relate to sediment-bearing shellfish gathering techniques in the Sado estuarine marshes, where they would be naturally deposited by slope and fluvial processes. Miocene calcareous rocks occur at the bottom of the valley, on the banks of Arapouco (the most downstream shell midden) and at the confluence of the Alcáçovas brook with the Sado (Fig. 10), outside the shell middens area. Therefore, the areas of the valley adjacent to the mentioned outcrops, where calcareous rocks are more exposed and susceptible to erosion and reworking into the fluvial bed, could be the source of the calcareous pebbles. They show some evidence of exposure to fire e.g. cracks and calcination (Fig. 9a, e), eventually related to the combustion activities in which charcoal and burnt bones and shells of $\mathrm{mF}$ type 3a would have originated. Foraminifera (Fig. 6g, h) are another significant component, identified exclusively in $\mathrm{mF}$ types $3 \mathrm{a}$ and $3 \mathrm{~b}$, associated with an estuarine marsh environment and equally interpreted as a by-product of shellfish gathering. For all these reasons, we interpret the presence of calcareous pebbles as unintentional inputs brought with the shellfish by the Mesolithic occupants of Poças de São Bento. Furthermore, this hypothesis can indicate the preferential location of shellfish gathering, which might not have been carried out near the site, but $\sim 8-12 \mathrm{~km}$ downstream in the river.

Overall, $\mathrm{mF}$ type $3 \mathrm{a}$ is interpreted as intentional anthropogenic displacement of previously deposited sediments, mixing remains from different activities, possibly by dumping or raking-out. The resulting deposits, according to experimental studies (Miller et al. 2010), also exhibit a high porosity and chaotic organisation of poorly sorted, burnt and unburnt components. Given the considerable extension of $\mathrm{mF}$ type $3 \mathrm{a}$ deposits in Poças de São Bento, it seems that the occupants of the site proceeded to spread these sediments around, in more or less juxtaposed accumulations. Such accumulations exhibit gradual horizontal boundaries in the field. A possible cause of reworked anthropogenic deposits, proposed by Aldeias and Bicho (2016) at Cabeço da Amoreira, is that the occupants were attempting to level the area in order to create a more stable and flat surface. Accordingly, we suggest a similar type of activity at Poças de São Bento.

Concerning $\mathrm{mF}$ type $3 \mathrm{~b}$, coarse inorganic, its main difference is a scarcity of organic components compared to $\mathrm{mF} 3 \mathrm{a}$, and a predominance of silty sand matrix, abundant micritic impregnations and randomly distributed, fragmented shells. The micromass of $\mathrm{mF}$ type $3 \mathrm{~b}$ is also less organic when compared to $\mathrm{mF}$ type $3 \mathrm{a}$. The lesser abundance of anthropogenic components other than shells seems to indicate that this $\mathrm{mF}$ type might have resulted from reworking sediments that originally also did not contain such components. The origin of these sediments is for the moment unclear, but a possible explanation could be an older reworking history that could have progressively eliminated the organic components. Microfacies $3 \mathrm{~b}$ was identified only in Area 9. The thickness of this deposit $(\sim 10 \mathrm{~cm}$.) and lack of any internal sedimentary structures (e.g. graded or well sorted bedding) lead us to exclude a natural process as responsible for this deposit, since it would imply a localised high-energy event, which is difficult to envision. This deposit over- and underlies two 
different deposits of $\mathrm{mF}$ type $5 \mathrm{a}$ (Fig. $2 \mathrm{~b}$ and 11), thus indicating that the shell midden sequence at Area 9 was formed by alternatingly events of single tossing and mass loads of reworked sediments.

\section{Occupational surfaces}

Microfacies type 4, horizontally oriented shells, is individualised by the occurrence of discrete stringers of interconnected shells, in sub-horizontal position, with high degree of in situ crushing (Fig. 9c, d). These attributes are interpreted as the result of intense trampling, pointing to possible remains of occupational surfaces i.e. the exposed surface of an area of the site that people frequented more. It is not possible to individualise these sediments into field excavation units, but the unifying attribute of $\mathrm{mF}$ type 4 (stringers of interconnected shells crushed in situ) displays remarkable consistence in two thin sections. The corresponding samples, PSB104 and PSB107, were collected at similar elevations in the North profile of Area 1 and are separated from each other by $\mathrm{c}$. $1 \mathrm{~m}$, suggesting that they are the same layer (Fig. 9a, b; see also Fig. 2c for spatial correlation between the two samples). The sediments of $\mathrm{mF}$ type 4 , horizontally oriented shells, overlie anthropogenically reworked $\mathrm{mF}$ type 3 a sediments in both thin sections. This is one of the most interesting outcomes of the microstratigraphic approach at Poças de São Bento, since it reveals internal stratigraphic consistency within the quite extensive, apparently homogenous, (and only) shell midden layer in Area 1. Another valuable outcome is that this association of possible occupational surfaces overlying anthropogenically dumped sediments is also present at Cabeço da Amoreira shell midden, an association used by the authors to reinforce the inference that $\mathrm{mF} 3$ a sediments were dumped to flatten the surface (Aldeias and Bicho 2016). More samples would have to be analysed from further $\mathrm{mF}$ type 3 a deposits in other areas of the site to make site-scale extrapolations. In Area $1, \mathrm{mF}$ type 4 is also overlaid by $\mathrm{mF} 3 \mathrm{a}$, and thus it seems that a new load of reworked anthropogenic materials was dumped over an occupational surface.

In Area 9, the $\mathrm{mF}$ type 3b, coarse inorganic, also interpreted as an anthropogenically reworked deposit, is not overlaid by $\mathrm{mF}$ type 4 , horizontally oriented shells. Further research on the differences between $\mathrm{mF}$ types $3 \mathrm{a}$ and $3 \mathrm{~b}$ in other parts of the site would possibly clarify a probable difference also in the intentions behind the general dumping actions argued for on $\mathrm{mF}$ type 3 , matrix-supported shells sediments.

\section{Dune stabilisation: the middle Holocene palaeosol}

The Pleistocene/Holocene sand cover, and the shell midden resting over it, reached a period of stabilisation that allowed the development of a vegetated A horizon, which has been classified as palaeosol A1 (phase C of Arias et al. (2015); see Table 1). These sediments correspond, in thin section, to $\mathrm{mF} 2$, unsorted sand and polymorphic fine organic matter. The sand grains in $\mathrm{mF} 2$ are more poorly sorted than in underlying deposits, with higher abundance of coarse sand grains, especially when compared to the Pleistocene/Holocene sand cover. This suggests the onset of a different sediment source, which is somewhat difficult to identify. Elsewhere, Duarte et al. (2015) suggested that this phase represents a shift in the environmental conditions that allowed the development of the palaeosol A1, which was inferred to represent more water availability from rainfall. The enrichment in polymorphic fine organic matter and the spongy microstructure are the key elements indicating that this deposit corresponded to a vegetated surficial soil. Polymorphic fom has been commonly found in spodic horizons (Buurman and Jongmas 20,015) (podzols have been reported in the area by Arnaud (2000)) but also in wellaerated, sandy soils. Curiously, it occurs in Brazilian "shellmounds with a sandy core" described by Villagran (2014b), although, here, polymorphic fom is related to anthropogenic inputs of organic carbon. In Poças de São Bento, there is no clear indicator that this amount of organic matter could be anthropogenically introduced, given the general lack of anthropogenic structures in this layer. The action of microbial and mesofaunal transformation of plant material into degraded and more or less welded organic aggregates of polymorphic fom takes place in the A-horizon of vegetated soils, which can occur with spongy microstructures (Wilson and Righi 2010), as in the case of $\mathrm{mF} 2$.

The striking black colour of these sediments in the field (Fig. 2b, c) is due to organic matter, and its maximum thickness (c. $40 \mathrm{~cm}$ ) suggests that this soil was exposed for a considerably long time (e.g. centuries), which led to the development of a thick vegetation cover. Furthermore, the fifth millennium cal BC radiocarbon dates obtained for samples of total organic matter from palaeosol A1 at the top of this layer in Area 6 (see Table 1) are consistent with the archaeological content of this layer, including sparse pottery sherds. However, the nature of the Neolithic presence at Poças de São Bento (as in other shell midden sites of the Sado Valley) remains an open question.

The palaeosol formation processes triggered some postdepositional alterations observed in the studied sediments. Soils are the dynamic product of chemical and physical weathering, and biological processes. Of particular interest at Poças de São Bento is the loss of material during periods of hydrologically effective precipitation, which leads to calcite dissolution and reprecipitation lower in the soil profile (Fairchild and Baker 2012). The soil 
microbial community, inferred from the studied sediments, is a source of soil $\mathrm{CO}_{2}$, along with root respiration (Witkamp and Frank 1969); this $\mathrm{CO}_{2}$ generates the soil water acidity that enhances hydrolysis reactions, and the dissolution of carbonate clasts (shells). In our case, chemical weathering of Mesolithic sediments is evident by the hydrolysis of feldspars and their alteration to sericite (the main alteration mineral for feldspars and petrographically recognisable by small equidimensional crystal masses of grey to black interference colour replacing the feldspar crystal) and the partial dissolution of shell fragments in $\mathrm{mF}$ type $2 \mathrm{a}$, the most surficial shell-rich sediments. The reprecipitation of these carbonates, lower in the soil profile, generates the pendants and the cemented areas in $\mathrm{mF}$ types 3, 6 and 7 (Figs. 6c, e and 8).

\section{Spatial organisation}

The human activities inferred from the micromorphological observation of anthropogenic sediments at Poças de São Bento revealed a clear intra-site differential use of space.

In Area 1, the shell midden layers revealed an occupational surface with signs of intense trampling, overlying a dumping of reworked activity debris, suggesting that this area was intensively occupied. Furthermore, in Area 1, the shell midden layer filled a pit excavated in the sand cover (Fig. 2b), a type of feature normally associated with residential purposes. In the future, micromorphological analysis of this pit infill (shell-rich sediments macroscopically homogeneous and similar to the shell midden layer itself) can potentially provide more detailed data on this aspect. The shell midden layer in Area 1 also contained the dog burial, evidence of more symbolic behaviour, in an area of the site that was occupied intensively.

The overlapping of different types of anthropogenic deposits in Area 9 suggests that this location corresponded to a preferential area of refuse of food items (shells and fish). Several superimposed single tossing events, intercalated with at least one sediment dumping event, can be clearly distinguished in thin section (Fig. $2 \mathrm{~b}$ and 11), suggesting that this specific location was used mainly for that effect. Little trampling and rapid burial indicators seem to suggest that Area 9 was immediately adjacent to a location where food consumption activities and subsequent tossing of the resulting debris repeatedly took place. This inference is interesting at the level of site-scale interpretations, given the proximity of Area 9 to the funerary area at Poças de São Bento.

\section{Living in the dunes: a seasonal or sedentary option?}

Settlement models have been proposed (e.g. Marchand 2001) in the framework of the hunter-gatherer economy of the Mesolithic groups in the Sado Valley. In general lines, the site has been regarded as a semi-sedentary basecamp, articulated with Cabeço do Pez (see Fig. 10) in seasonal cycles (Arnaud 1989, 2000). These hypotheses are based on their larger size and the relative significance of lithic industries and faunal records at these sites in comparison with other sites in the Sado Valley. The identification of residential structures (e.g. post-holes and fireplaces), and ecological characteristics of the area, particularly the existence of a freshwater source, were considered the mainstays supporting these hypotheses (Larsson 1996; Arnaud 2000).

The micromorphological analysis of the shell midden layers at Poças de São Bento can contribute to the temporal characterisation of, at least, the sampled contexts. The microstratigraphic record points to a rapid formation process characterised by quick and short events of anthropogenically deposited sediments. A possible exception is that of the few upper centimetres of $\mathrm{mF}$ type $6 \mathrm{a}$, silty sands with few shells, at the base of the shell midden. This is the only microfacies where the presence of shells is not clearly intentional but more likely explained by a combination of surficial rolling promoted by wind action over the already occupied dune and a nonintentional transport by humans (e.g. trampling).

Considering that aeolian processes might be active at the time of the shell midden formation and that there are topographically higher positions around the site, we can envision a very short time between each event in Area 9, at least, short enough to prevent natural wind-induced sedimentation to occur. The aforementioned indicators of rapid burial of $\mathrm{mF}$ type 5 , shell-supported sediments, also point to this hypothesis. For these reasons, we argue for an accumulation of the vertical sequence in Area 9 during the same period of occupation, rather than the result of events belonging to occupations separated by large periods of total abandonment of the site.

Concerning Area 1, microfacies analysis also provided evidence of superimposed anthropogenic deposits. A deposit resulting from anthropogenic reworking was overlaid by an occupational surface affected by intense trampling. That surface was later covered by a new load of reworked debris, of short enough duration to prevent natural sedimentation occurring. For the same reason as for Area 9, we think that these events took place during the same "occupation". At Cabeço da Amoreira, thin lenses of crudely bedded silt to fine sand were sometimes found overlying occupational surfaces, and then a new dumping event covered the lenses. This was used by the authors to argue for a temporary abandonment of, at least, that area of the site (Aldeias and Bicho 2016), which cannot be stated for the current sedimentary record of Poças de São Bento.

Overall, there are not enough data to distinguish sedimentologically different occupations in the vertical stratification at Poças de São Bento during the Mesolithic. One possible way 
to solve this question would be through isotopic analysis of the shells in order to establish seasonality patterns integrated with the microstratigraphic evidence for different episodes of shell accumulation while sampling.

\section{Conclusions}

The present study provided significant results for research on Mesolithic societies at Poças de São Bento, particularly regarding interpretation of the archaeological record. Concerning site-specific research questions, one of the most interesting outcomes of the micromorphological approach is that there was intentional superposition of shellrich sediments, and not only lateral juxtaposition of anthropogenic deposits, as systematically assumed in previous studies on the Sado shell middens. Our approach revealed the distinction between dumped sediments and occupational surfaces within the shell midden layer at Area 1. This layer is actually macroscopically equivalent to most of the shell-rich deposits in all the excavated areas at the site, and very often the only one. Our analysis suggests a full internal dynamic in the formation of this apparently homogeneous shell midden layer. This evidence points to the need for further micromorphological approaches in similar deposits in other areas of the site, especially the pit infillings, in order to track the areas and activities complementary to those inferred microscopically.

At a broader, Sado Valley scale, the remarkable occurrence of elements such as clay aggregates and foraminifera in anthropogenically reworked sediments most probably indicate transport of marshland components directly from the gathering place to the site, as a consequence of shellfish gathering techniques. Calcareous pebbles in the same sediments, when related to the regional geology, provide sedimentological evidence suggesting that the shellfish gathering was not carried out in the vicinity of the site, but $\sim 8-12 \mathrm{~km}$ downstream. These aspects have major implications regarding future studies of logistical movements of the Mesolithic hunter-gatherers in the valley, and also the pending question of the extension of the palaeo-estuary during that period.

From macroscopically visible stratified accumulations, such as at Area 9, we were able to recognise human actions such as preferential discard of debris, single tossing events, and dumping of intentionally reworked sediments. The results show a lack of evidence of abandonment periods inside these deposits. This is an open question that could be investigated in the future. Particularly interesting for this issue are seasonality studies through isotopic analysis of the shells, based on the microstratigraphy of the different human-induced sedimentary events in order to prevent inadvertent mixing of materials from different events in the sampling of archaeological materials.

Tossing of debris, sediment dumping and spreading out, trampling and preferential refuse areas are some of the activities, inferred from the microstratigraphic record that Poças de São Bento has in common with Cabeço da Amoreira. These similarities appear to be revealing the same anthropogenic patterns in the activities involved in the formation of both sites. These observations open new research possibilities for other similar contexts regarding more general behavioural dynamics. The study of shell midden formation processes, through microcontextual approaches, has played a major role in our knowledge of Mesolithic societies at the two largest early Holocene estuarine ecological settings of the central/south Portuguese coast.

Acknowledgements This research was possible thanks to a $\mathrm{PhD}$ scholarship Formación de Personal Investigador (BES-2012-053695) granted to CD by the Spanish Ministry of Economy and Competitiveness. Fieldwork at Poças de São Bento and thin section production was conducted in the framework of "Sado-Meso" project, an international collaboration made possible by several projects over the last years: "COASTTRAN - Coastal transitions: A comparative approach to the processes of neolithization in Atlantic Europe" (HAR2011-29907-C0300) (P.I.: PA) and "Co-Change - Coastal societies in a changing world: A diachronic and comparative approach to the Prehistory of SW Europe from the late Palaeolithic to the Neolithic" (HAR2014-51830-P) (P.I.: PA), both funded by the Spanish Ministry of Economy and Competitiveness, and the project "Back to Sado: a case among the last hunter-gatherers and farmers' societies emergence in the South of Portugal" (PTDC/HIS-ARQ/121592/2010) (P.I.: MD), funded by the Portuguese Fundação para a Ciência e Tecnologia. We would like to thank Luis Teira for the topographic and photogrammetric data production and edition for this work, and Monica Alonso for help in phytolith identification. A special thanks to Vera Aldeias for her comments on an earlier version of this paper; we are very grateful to her and Ximena Villagran for productive discussion on the thin section analysis and some of the ideas expressed in this paper. Finally, we are very grateful to the two reviewers for their comments that improve the manuscript.

\section{References}

Aldeias V, Bicho N (2016) Embedded behavior: human activities and the construction of the Mesolithic Shellmound of Cabeço da Amoreira, Muge, Portugal. Geoarchaeology 31:530-549

Aldeias V, Goldberg P, Sandgathe D, Berna F, Dibble HL, Mcpherron SP, Turq A, Rezek Z (2012) Evidence for Neandertal use of fire at roc de Marsal (France). J Archaeol Sci 39:2414-2423

Aldeias V, Goldberg P, Dibble HL, El-Hajraoui M (2014) Deciphering site formation processes through soil micromorphology at Contrebandiers Cave, Morocco. J Hum Evol 69:8-30

Aldeias V, Gur-Arieh S, Maria R, Monteiro P, Cura P (2016) Shell we cook it? An experimental approach to the microarchaeological record of shellfish roasting. Archaeol Anthropol Sci:1-19. doi:10. 1007/s12520-016-0413-1

Ãlvarez M, Briz Godino I, Balbo A, Madella M (2011) Shell middens as archives of past environments, human dispersal and specialized resource management. Quat Int 239:1-7 
Araújo AC (1995-1997) A indústria lítica do concheiro de Poças de S. Bento (Vale do Sado) no seu contexto regional. O Arqueólogo Português. Serie IV 13-15:87-159

Araújo, A. C., Arias, P. \& Diniz, M. 2015. Lithics in a Mesolithic shell mound: new data from Poças de São Bento (Portugal). In: Bicho, N., Cunha, E., Detry, C. \& Price, T. D. (eds.) Muge 150th: the 150th anniversary of the discovery of the Mesolithic shellmiddens. Cambridge Scholars Publishing.

Arias, P., Diniz, M., Araújo, A. C., Armendáriz, Á. \& Teira, L. C. 2015. At the edge of the marshes: new approaches to the Sado valley Mesolithic (southern Portugal). In: Bicho, N., Detry, C., Price, D. T. \& Cunha, E. (eds.) Muge 150th: The 150th Anniversary of the Discovery of Mesolithic Shellmiddens. Volume 1.: Cambridge Scholars Publishing.

Arnaud JM (1989) The Mesolithic communities of the Sado Valley, Portugal in their ecological setting. The Mesolithic in Europe International Symposium 3:614-631

Arnaud JM (2000) Os concheiros mesolíticos do vale do Sado e a exploração dos recursos estuarinos (nos tempos pré-históricos e na actualidade). Actas do Encontro sobre Arqueologia da Arrábida, Trabalhos de Arqueologia 4:21-43

Arpin TL, Mallol C, Goldberg P (2002) Short contribution: a new method of analyzing and documenting micromorphological thin sections using flatbed scanners: applications in geoarchaeological studies. Geoarchaeology 17(3):305-313

Balbo AL, Madella M, Vila A, Estévez J (2010) Micromorphological perspectives on the stratigraphical excavation of shell middens: a first approximation from the ethnohistorical site Tunel VII, Tierra del Fuego (Argentina). J Archaeol Sci 37:1252-1259

Balbo A, Madella M, Godino IB, ÃLvarez M (2011) Shell midden research: an interdisciplinary agenda for the quaternary and social sciences. Quat Int 239:147-152

Bicho N, Umbelino C, Detry C, Pereira T (2010) The emergence of Muge Mesolithic Shell Middens in Central Portugal and the 8200 cal yr BP cold event. The Journal of Island and Coastal Archaeology 5:86104

Bicho N, Cascalheira J, Marreiros J, Pereira T (2011) The 2008-2010 excavations of Cabeço da Amoreira, Muge, Portugal. Mesolithic Miscellany 21:3-13

Bicho N, Cascalheira J, Marreiros J, Gonçalves C, Pereira T, Dias R (2013) Chronology of the Mesolithic occupation of the Muge valley, central Portugal: the case of Cabeço da Amoreira. Quat Int 308-309: 130-139

Buurman P, Jongmans AG (2005) Podzolisation and soil organic matter dynamics. Geoderma 125:71-83

Buurman P, Van Bergen PF, Jongmans AG, Meijer EL, Duran B, Van Lagen B (2005) Spatial and temporal variation in podzol organic matter studied by pyrolysis-gas chromatography/mass spectrometry and micromorphology. Eur J Soil Sci 56:253-270

Colonese AC, Troelstra S, Ziveri P, Martini F, Lo Vetro D, Tommasini S (2009) Mesolithic shellfish exploitation in SW Italy: seasonal evidence from the oxygen isotopic composition of Osilinus turbinatus shells. J Archaeol Sci 36:1935-1944

Colonese AC, Verdún-Castelló E, Álvarez M, Briz I, Godino I, Zurro D, Salvatelli L (2012) Oxygen isotopic composition of limpet shells from the Beagle Channel: implications for seasonal studies in shell middens of Tierra del Fuego. J Archaeol Sci 39:1738-1748

Costa, A. M., Freitas, M. C., Arias, P., Diniz, M., Araújo, A. C., Andrade, C., Rodrigues, A., Duarte, J., Cachão, M., Leira, M. 2015. Lower Sado basin sediments: a source for information for the late Mesolithic behaviour. Proceeding of Progress in Quaternary Archive Studies in the Iberian Peninsula, Seville, March 2015

Costa, A. M., Freitas, M. C., Arias, P., Diniz, M., Araújo, A. C. 2017. Sado River sediments as a major source of information to recostruct Mesolithic landscapes. Paper accepted to be delivered at the 1st
Meeting of Histories of Nature and Environment: Dialogues and Perspectives, Lisbon, March 2017.

Courty M-A (2001) Microfacies analysis assisting archaeological stratigraphy. In: Goldberg P, Holliday VT, Ferring CR (eds) Earth sciences and archaeology. Boston, MA, Springer US

Courty M-A, Fedoroff N (2002) Micromorphologie des sols et sédiments archéologiques. In: Miskovsky J-C (ed) Géologie de la Préhistoire: méthodes, techniques, applications. Presses Universitaires de Perpignan, Paris

Courty M, Goldberg P, Macphail R (1989) Soils and micromorphology in archaeology. Cambridge University Press, Cambridge, Cambridge

Dias JMA, Boski T, Rodrigues A, Magalhães F (2000) Coast line evolution in Portugal since the last glacial maximum until present - a synthesis. Mar Geol 170:177-186

Diniz, M. T. \& Arias, P. 2012. O povoamento humano do paleo-estuário do Sado (Portugal): problemáticas em torno da ocupação dos concheiros mesolíticos. In: Almeida, A. C., Bettencourt, A. M. S., Moura, D., Monteiro-Rodrigues, S. \& Alves, M. I. C. (eds.) Environmental changes and human interaction along the Western Atlantic edge / Mundanças ambientais e interação humana na fachada atlântica ocidental. Coimbra: APEQ-CITCEM-CEGOTCGUP-CCT.

Duarte, C., Iriarte, E., Diniz, M. \& Arias, P. 2015. High resolution XRF chemostratigraphy of the Poças de São Bento shell midden (Sado valley, Portugal). In: Bicho, N., Detry, C., Price, D. T. \& Cunha, E. (eds.) Muge 150th: The 150th Anniversary of the Discovery of Mesolithic Shellmiddens. Volume 1.: Cambridge Scholars Publishing.

Durand N, Monger HC, Canti MG (2010) 9 - Calcium Carbonate Features. In: Stoops G, Marcelino V, Mees F (eds) Interpretation of Micromorphological features of soils and Regoliths. Elsevier, Amsterdam

Fairchild, I.J. \& BakeR, A. 2012. Speleothem Science: from processes to past environments. Wiley-Blackwell.

Flügel E (2004) Microfacies of carbonate rocks. Springer, Berlin Heidelberg

Fontanals-Coll M, Subirà ME, Marín-Moratalla N, Ruiz J, Gibaja JF (2014) From Sado Valley to Europe: Mesolithic dietary practices through different geographic distributions. J Archaeol Sci 50:539 550

French C (2003) Geoarchaeology in action: studies in soil micromorphology and landscape evolution. Routledge, London

Goldberg P, Aldeias V (2016) Why does (archaeological) micromorphology have such little traction in (geo)archaeology? Archaeol Anthropol Sci. doi:10.1007/s12520-016-0353-9

Goldberg P, Berna F (2010) Micromorphology and context. Quat Int 214: $56-62$

Goldberg P, Schiegl S, Meligne K, Dayton C, Conard N (2003) Micromorphology and site formation at Hohle Fels Cave, Swabian Jura, Germany. Eiszeit Gegenw 53:1-25

Goldberg P, Miller CE, Schiegl S, Ligouis B, Berna F, Conard NJ, Wadley L (2009) Bedding, hearths, and site maintenance in the middle stone age of Sibudu Cave, KwaZulu-Natal, South Africa. Archaeol Anthropol Sci 1:95-122

Goudie AS (2017) Eolian settings: sand. In: Gilbert AS (ed) Encyclopedia of Geoarchaeology. Springer Netherlands, Dordrecht

Gutiérrez-Zugasti I, Andersen SH, Araújo AC, Dupont C, Milner N, Monge-Soares AM (2011) Shell midden research in Atlantic Europe: state of the art, research problems and perspectives for the future. Quat Int 239:70-85

Gutiérrez-Zugasti I, García-Escárzaga A, Martín-Chivelet J, GonzálezMorales MR (2015) Determination of sea surface temperatures using oxygen isotope ratios from Phorcus lineatus (da Costa, 1778 ) in northern Spain: implications for paleoclimate and archaeological studies. The Holocene 25:1002-1014 
Karkanas P (2002) Micromorphological studies of Greek prehistoric sites: new insights in the interpretation of the archaeological record. Geoarchaeology 17:237-259

Larsson L (1996) Late Atlantic settlement in southern Portugal. Results of an excavation of a Mesolithic shell midden by the river Sado. Current Swedish Archaeology 4:123-139

Larsson L (2010) Shells in the sand. Poças de São Bento-a Mesolithic shell midden by the river Sado, southern Portugal. In: Armbruester $\mathrm{T}$, Hegewisch M (eds) On pre- and earlier history of Iberia and Central Europe: studies in honour of Philine Kalb. Bonn, Habelt

López-Dóriga I (2016) The use of plants during the Mesolithic and the Neolithic in the Atlantic coast of the Iberian peninsula. Universidad de Cantabria, Dissertation

López-Dóriga I, Diniz M, Arias P (2016) Macrobotanical remains and shell-midden formation processes, are they related? The case of Poças de São Bento (Portugal). Archaeol Anthropol Sci:1-13. doi: 10.1007/s12520-016-0429-6

Mallol C, Mentzer SM (2015) Contacts under the lens: perspectives on the role of microstratigraphy in archaeological research. Archaeol Anthropol Sci:1-25

Mallol C, Cabanes D, Baena J (2010) Microstratigraphy and diagenesis at the upper Pleistocene site of Esquilleu Cave (Cantabria, Spain). Quat Int 214:70-81

Marchand G (2001) Les traditions techniques du Mésolithique final dans le sud du Portugal: les industries lithiques des amas coquilliers de Várzea da Mó et de Cabeço do Rebolador (fouilles M. Heleno) Revista Portuguesa de. Arqueologia 4(2):47-110

Mentzer SM (2014) Microarchaeological approaches to the identification and interpretation of combustion features in prehistoric archaeological sites. J Archaeol Method Theory 21:616-668

Miller CE, Conard NJ, Goldberg P, Berna F (2010) Dumping, sweeping and trampling: experimental micromorphological analysis of anthropogenically modified combustion features. In: Théry-Parisot, I., Chabal, L. \& Costamagno S. (eds.) The taphonomy of burned organic residues and combustion features in archaeological contexts, proceedings of the round table, May 27-29 2008. Palethnologie 2: $25-37$

Miller CE, Goldberg P, Berna F (2013) Geoarchaeological investigations at Diepkloof rock shelter, Western cape, South Africa. J Archaeol Sci 40:3432-3452

Peyroteo Stjerna R (2016) On death in the Mesolithic: or the mortuary practices of the last hunter-gatherers of the south-Western Iberian peninsula, 7th-6th millennium BCE. Uppsala University, Department of Archaeology and Ancient History

Pimentel N, Azevêdo TM (1994) Etapas e controlo alpino da sedimentação na bacia do Sado (SW de Portugal). Cadernos do Laboratorio Xeolóxico de Laxe: Revista de xeoloxía galega e do hercínico peninsular 19:229-238

Pimentel, N., Nukushina, D., Diniz, M. \& Arias, P. 2015. Lithic materials in the Sado River's shell middens: geological provenance and impact on site location. In: Bicho, N., Cunha, E., Detry, C. \& Price, T. D. (eds.) Muge 150th anniversary of the discovery of the Mesolithic shellmiddens. Cambridge Scholars Publishing.
Roche J (1966) Balance de un siglo de excavaciones en los cocheros mesol'iticos de Muge. Empúries: revista de món clàassic i antiguitat tardana, 13-48

Scholle PA, Ulmer-Scholle DS (2003) A color guide to the petrography of carbonate rocks: grains. Textures, Porosity, Diagenesis, Tulsa, AAPG

Sherwood SC, Kidder TR (2011) The DaVincis of dirt: geoarchaeological perspectives on native American mound building in the Mississippi River basin. J Anthropol Archaeol 30:69-87

Shillito L-M, Matthews W, Almond MJ, Bull ID (2011) The microstratigraphy of middens: capturing daily routine in rubbish at Neolithic Çatalhöyük, Turkey. Antiquity 85:1024-1038

Stein J (1992) Deciphering a shell midden. Academic Press, San Diego

Stjerna, R. P. 2015. Death in place: rituals in practice. In: Von Hackwitz, K. \& Peyroteo Stjerna, R. (eds.) Ancient death ways, Occasional Papers in Archaeology 59.

Stoops G (2003) Guidelines for analysis and description of soil and regolith thin sections. Soil Science Society of America Inc., Madison, Wisconsin

Surge D, Wang T, Gutierrez-Zugasti I, Kelley PH (2013) Isotope sclerochronology and season of annual growth line formation in limpet shells (Patella vulgata) from warm-and cold-temperate zones in the eastern North Atlantic. PALAIOS 28:386-393

Umbelino, C., Pérez-Pérez, A., Cunha, E., Hipólito, C., Freitas, M. D. C. \& Cabral, J. P. 2007. Outros sabores do passado: um novo olhar sobre as comunidades humanas mesolíticas de Muge e do Sado através de análises químicas dos ossos. Promontoria, Revista do Departamento de História, Arqueologia e Património da Universidade do Algarve, 45-90.

Villagran XS (2014a) Experimental micromorphology on burnt shells of Anomalocardia brasiliana (Gmelin 1791) (Bivalvia, Veneridae) and its potential for identification of combustion features on Shell-matrix sites. Geoarchaeology 29:389-396

Villagran XS (2014b) A redefinition of waste: deconstructing shell and fish mound formation among coastal groups of southern Brazil. J Anthropol Archaeol 36:211-227

Villagran XS, Giannini PC (2014) Shell mounds as environmental proxies on the southern coast of Brazil. The Holocene 24:1009-1016

Villagran XS, Giannini PCF, Deblasis P (2009) Archaeofacies analysis: using depositional attributes to identify anthropic processes of deposition in a monumental shell mound of Santa Catarina State, southern Brazil. Geoarchaeology 24:311-335

Villagran XS, Balbo AL, Madella M, Vila A, Estevez J (2011) Stratigraphic and spatial variability in shell middens: microfacies identification at the ethnohistoric site Tunel VII (Tierra del Fuego, Argentina). Archaeol Anthropol Sci 3:357-378

Wilson MA, Righi D (2010) 12 - Spodic Materials. In: Stoops G, Marcelino V, Mees F (eds) Interpretation of Micromorphological features of soils and Regoliths. Elsevier, Amsterdam

Witkamp M, Frank ML (1969) Evolution of CO2 from litter, humus, and subsoil of a pine stand. Pedobiologia 9:358-365

Zerboni A (2011) Micromorphology reveals in situ Mesolithic living floors and archaeological features in multiphase sites in central Sudan. Geoarchaeology 26:365-391 